\title{
Genomics of Basal and Squamous Cell Carcinomas
}

\author{
Venura Samarasinghe ${ }^{1,2}$, John T. Lear ${ }^{1,2}$, Vishal Madan ${ }^{1,2}$ \\ ${ }^{1}$ The Dermatology Centre, Hope Hospital, Manchester \\ ${ }^{2}$ Central Manchester Dermatology Centre, Manchester
}

UK

\section{Introdcution}

Non-melanoma skin cancers, which include basal and squamous cell cancers, are the most common human cancers. Because of their relatively low metastatic rate and relatively slow growth these are frequently underreported. The high prevalence and the frequent occurrence of multiple primary tumours in affected individuals make non-melanoma skin cancers an important but underestimated public health problem.

There has been a dramatic increase in the incidence of non-melanoma skin cancer in the past 40 to 50 years, despite the awareness of the harmful effects of excessive sun exposure. A population-based study from Wales has shown that the crude incidence for non-melanoma skin cancer has increased from 173.5 to 265.4 per 100,000 population per annum between 1988 and 1998 (Holme et al, 2000, Br J Dermatol).

Although ultraviolet radiation is the most important risk factor in the genesis of both squamous cell carcinomas and basal cell carcinomas, there is a proportionately greater effect of increasing sun exposure on the risk of developing squamous cell carcinoma (Kricker et al, 1995, Int J Cancer). The desirability of a tan, increased leisure time and the introduction of cheap package holidays have resulted in a marked increase in the levels and change of pattern of sun exposure in the last 4 to 5 decades and this is thought to have led to an increase in the incidence of NMSC.

Basal cell carcinomas (BCC) which are the commonest cancer in Caucasians are slow growing tumour which, rarely metastasize. Their incidence is increasing by $\sim 10 \% /$ year worldwide indicating that the prevalence of this tumour will soon equal that of all other cancers combined (Karagas et al, 1995, Skin cancer: Mechanisms and human relevance). Furthermore, $40-50 \%$ of patients will develop at least one more within 5 years.

UV radiation is the major aetiological agent in the pathogenesis of BCC and an understanding of its effects on the skin is clearly critical. However, though exposure to UVR is essential, its relationship with risk is unclear and epidemiological studies suggest its quantitative effect is modest. For example, a large European case-control study has shown only a two-fold increase in risk with increased exposure (Rosso et al, 1996, Br J Can) while recent studies suggest that intermittent rather than cumulative exposure is more important 
(Kricker, 1995, Int J Cancer). The relationship between tumour site and exposure to UVR is also unclear. The distribution of lesions does not correlate well with the area of maximum exposure to UVR in that BCC are common on the eyelids, at the inner canthus and behind the ear, but uncommon on the back of the hand and forearm. Indeed, compared with squamous cell cancer (SCC), BCC are relatively more common on less exposed sites such as the trunk. Thus, though exposure to UVR is critical, patients develop BCC at sites generally believed to suffer relatively less exposure. The basis of the different susceptibility of skin at different sites to BCC development is not known, but may be related to the association of BCC with intermittent UV exposure.

Surgery remains the mainstay in the treatment of BCC. However, with a better understanding of the aetiopathogenesis and the relatively non- aggressive nature of these lesions, newer forms of destructive and non- destructive treatments are a focus of research. Induction of apoptosis, modulation of differentiation and immunomodualtion are some of the strategies by which some of the current pharmacotherapeutic agents exert their action. Unravelling the genetics of BCC will provide a basis for further research on the introduction of pharmacogenetics and development of newer agents targeting the specific genes implicated in the causation of BCC.

Chronic irritation, inflammation and injury to the skin can predispose to malignant epithelial neoplasms, in particular squamous cell carcinomas (Kaplan, 1987, Adv Derm). Examples include complicated scars from frostbite, electrical injury, chronic sinuses or fistulas, chronic osteomyelitis, chronic stasis dermatitis, and scars following various cutaneous infections.

The most often reported dermatoses complicated by cancer are discoid lupus erythematosus, scarring variants of epidermolysis bullosa, genital lichen sclerosus et atrophicus, its variant balanitis xerotica obliterans and lichen planus.

Lupus vulgaris, a chronic form of cutaneous tuberculosis is complicated by squamous cell carcinoma or less commonly basal cell carcinomas in up to $8 \%$ of the patients (Betti et al 2002, Hautarzt, Forstrum et al, 1969, Ann Clin Res ). Squamous cell cancers can also arise from lesions of erythema $a b$ igne, a characteristic dermatosis resulting from repeated or prolonged exposure to infrared radiation, insufficient to produce a burn (Peterkin, 1955, BMJ).

There is strong evidence that Photochemotherapy (PUVA) increases the risk of developing squamous cell carcinoma and this correlates with the cumulative dose of ultraviolet A. High dose PUVA (more than 200 treatments) is associated with a 14- fold increase in the risk of NMSC compared to low dose PUVA (Stern et al, 1998 Arch Dermatol). Arsenic is an important chemical carcinogen implicated in the development of non-melanoma skin cancer. In the first half of the 20th century, this was caused by the ingestion of medicinal arsenic in the form of medications for asthma and psoriasis. Mining and well water which is high in arsenic are the main sources today.

Patients who have received a renal transplant have a 50-250-fold increased risk of developing squamous cell carcinoma and a 5-10 fold increase in the risk of developing basal cell carcinoma implicating anti-tumour immunity (McGregor et al, 1995, Lancet, Bouwes Bavinck, 1995, Hum Exp Toxicol). Moreover, there is a close association between the 
development of non-melanoma skin cancer and premalignant lesions such as actinic keratoses and the presence of viral warts in these patients (Bouwes Bavinck, 1995, Hum Exp Toxicol). Actinic keratoses are hyperkeratotic lesions occurring on chronic light exposed adult skin, and carry a low risk of progression to invasive squamous cell carcinoma. Lesions are usually multiple and comprise of macules or papules with a rough scaly surface resulting from disorganised keratinisation and a variable degree of inflammation. Although the rate of progression of individual squamous cell carcinoma has been estimated to be less than $0.1 \%$, the presence of actinic keratoses is an important marker of excessive UV exposure and increased risk of non-melanoma skin cancer (Salasche, 2000, J Am Acad Dermatol)

Mucosal lesions such as leukoplakias are also known to be premalignant with 2-5\% becoming malignant in 10 years (Crispian, 2004, Rooks textbook of Dermatology, Blackwell publishing). Bowen's disease is a form of intraepidermal squamous cell carcinoma, which presents as a persistent, non-elevated, red, scaly or crusted plaque and carries a small potential of invasive spread. Most studies suggest a risk of invasive cancer of about $3 \%$. There is a significant frequency of multiple lesions and an association of Bowen's disease with other skin cancers, which may reflect predominant solar aetiology or, in some cases exposure to arsenic. Genital, especially perianal Bowen's disease has a higher risk of invasive malignancy.

Various studies indicate that the risk of skin cancer may be related to the overall amount of immunosupression (Jensen, 1999, Science, Bouwes Bavinck ,1996, Transplantation, Dantal, 1998, Lancet). Skin cancers are the most common malignancies that occur in transplant patients and their frequency increases with time after transplantation (Penn, 1993,Hematol Oncol Clin North Am). The normal SCC/BCC ratio as observed in normal population is reversed in transplant recipients, with an excess in SCC development (Ong et al, 1999, J Am Acad Dermatol, Barr et al, 1989, Lancet) Moreover, these tumours behave more aggressively with a higher risk of metastasis than in general population (Penn, 1991, Transplant Proc).

Patients receiving renal transplant from HLA -B antigen mismatched donors, are at a higher risk of developing SCC, which is thought to be related to more intense immunosupression which these patients receive (Bouwes Bavinck et al 1991,N Engl J Med.). SCC in transplant patients develop mostly on sun exposed sites (Bavinck et al 1993,Br J Dermatol.) and are more frequent in individuals with fair skin, blue eyes, and blonde and red hair (Bavinck et al 1993,Br J Dermatol., Euvrard et al 1995, J Am Acad Dermatol, McLelland et al 1998, Transplantation.); the standard risk factors for development of SCC. Early diagnosis and treatment of squamous cell cancers is important to avoid metastasis and tissue destruction as these cancers are more invasive and have a higher metastatic spread compared to basal cell cancers.

\section{SCC predisposing syndromes}

\subsection{Xeroderma pigmentosum}

An autosomal recessive disease characterised by elevated sensitivity to sunlight, multiple epidermal skin cancers in childhood as a consequence of increased susceptibility to DNA damage and abnormal DNA repair. In vitro, cells from XP patients show a decreased ability 
to conduct base excision repair in which single strand areas of DNA are excised and replaced with a new set of bases after sunlight induced damage.

\subsection{Albinism}

Partial or complete failure to produce melanin in the skin and the eyes. SCC and melanoma develop in sun exposed sites of most individuals at an early age. (Lookingbill et al 1995, J Am Acad Dermatol.)

\subsection{Muir Torre syndrome}

Germ line mutations in genes involved in DNA mismatch repair and microsatellite instability result in this autosomal dominant syndrome characterised by the presence of one or more sebaceous neoplasms in association with internal malignancy, most frequently of the colon. SCC have also been described in these patients.

\subsection{KID (Keratosis, Icthyosis, Deafness)}

Invasive SCC developing within dysplastic lesions have been reported in several patients suffering from this syndrome (Madariaga et al, 1986, Cancer).

\subsection{Dystrophic epidermolysis bullosa}

Recessive dystrophic epidermolysis bullosa (RDEB) is an autosomal recessive mechanobullous disorder caused by mutations in the human type VII collagen gene (COL7A1). Individuals with DEB lack type VII collagen and anchoring fibrils, structures that attach epidermis and dermis. The leading cause of death in RDEB is invasion and metastasis of cutaneous SCC. Although the SCC in RDEB are frequently well-differentiated by histopathology, they often have a poor prognosis due to multicentricity, rapid invasiveness, and development of distant metastases. Mutations in the p53 tumor suppressor gene and loss of p16ink4a through hypermethylation have been seen in cutaneous SCC from these patients (Arbiser et al, 2004, J Invest Dermatol). This suggests that alterations in both p53 and p16ink4a can contribute to SCC in RDEB. Patients with RDEB have also been found to have elevated levels of $\mathrm{b}$ fibroblast growth factor, which may contribute to increased fibroblast collagenase and the development of SCC (Arbiser et al, 1998, Mol Med). Reduced expression of IGFBP-3, as seen in SCC associated with RDEB, has been suggested as a likely reason for the aggressive behaviour and poor prognosis of these tumors (Mallipeddi et al, 2004, J Invest Dermatol).

\subsection{Fanconi anaemia}

Fanconi anemia is an autosomal recessive disorder characterized by congenital malformations, bone marrow failure, and the development of SCC and other cancers. Environmental factor such as human papillomavirus (HPV) may be involved in the pathogenesis of SCC in Fanconi anemia patients (Kutler et al 2003, J Natl Cancer Inst). HPV DNA was isolated in $84 \%$ of the SCC specimens from the patients with Fanconi anaemia and a large proportion of patients with Fanconi anemia and SCC were homozygous for Arg72, a p53 polymorphism that may be associated with increased risk for HPV-associated human malignancies (Kutler et al 2003,J Natl Cancer Inst). 


\subsection{Rothmund Thompson syndrome}

Rothmund-Thomson syndrome (RTS) is a rare autosomal recessive genodermatosis characterized by early onset of progressive poikiloderma including alopecia, dystrophic teeth and nails, juvenile cataracts, short stature, hypogonadism, bone defects and several other cutaneous and extracutaneous findings. Most (but apparently not all) cases of RTS are caused by null or hypomorphic mutations in the RECQL4 gene, a putative DNA helicase. A role for RECQL4 in the repair of DNA double-strand breaks by homologous recombination has been suggested (Petkovic et al, $2005 \mathrm{~J}$ Cell Sci). Several cases of skin malignancies including SCC have been described in RTS patients, indicating a higher incidence of cutaneous malignancies (Piquero-Casals et al 2002,Pediatr Dermatol).

\subsection{Werner syndrome}

Werner syndrome is a genetic disorder of early ageing, excess cancer risk, high incidence of type II diabetes mellitus, early atherosclerosis, ocular cataracts, and osteoporosis. The protein encoded by the defective gene, WRN (WRNp) associates with 3'-5'-exonuclease and ATPase activities. Werner syndrome protein (WRN) is a RecQ-type DNA helicase, which seems to participate in DNA replication, double-strand break (DSB) repair, and telomere maintenance. A deficiency in maintaining DNA integrity is thought to be a consequence of the defective DNA helicase. In vivo alterations of oxidative stress parameters in WS patients have been demonstrated which may cause oxidative damage to biomolecules, with multiple oxidative stress-related alterations, resulting in multi-faceted clinical consequences (Pagano et al, 2005, Biogerontology, Pagano et al, 2005, Free Radic Res).

\subsection{Other syndromes}

These include hereditary non-polyposis coli, dyskeratosis congenita, Huriez syndrome and chronic mucocutaneous candidiasis.

\section{Candidate susceptibility genes}

The concept of genetic susceptibility to BCC and SCC is complex as genes may influence susceptibility as well as tumour numbers, rate of appearance and site. Selection of putative susceptibility genes must be in part subjective though the varied effects of UVR suggest that candidate genes may be selected from those involved in DNA repair, defence against oxidative stress, immune modulation, tanning and other related biochemical activities.

Although sunlight plays a crucial role in the development of SCC and to a lesser extent BCC, there is enough evidence that this is process is multifactorial with contributions from genetic and environmental factors. Several genes have been implicated in providing protection against and modifying the effects of UV radiation. It is also understood that UV is both mutagenic and locally immunosuppressant, thereby implying a huge pathogenic potential.

\subsection{DNA repair}

Signature UV-DNA lesions, cyclobutane dimers and 6-4 photoproducts, are repaired via the nucleotide excision repair pathway which may be subdivided into transcription-coupled repair and global genome repair. The XPC protein is specific to this latter repair pathway 
recognizing helix distorting lesions and initiating their repair. Inactivating XPC mutations are associated with xeroderma pigmentosa and an extremely high risk of skin cancer. Most early research on DNA repair and skin cancer was performed in patients with xeroderma pigmentosum $(\mathrm{XP})$, a rare autosomal recessive syndrome in which multiple skin tumours are seen. Reduced capacity to repair DNA was observed in XP cells (Cleaver et al, 1969, Proc Natl Acad Sci USA). Early in life, homozygote XP patients develop severe photosensitivity and a 2,000-fold increased risk of skin cancer.

A common polymorphism in intron 9 of the XPC gene has been associated with both reduced repair of UV-DNA damage and increased risk of squamous cell head and neck cancer. It has been reported that PAT+ polymorphism may slightly modify the risk of SCC among individuals with a phenotype which results in low UV-DNA adduct burdens (Nelson et al, 2005, Cancer Let $t$ ). The XPD is another gene involved in the nucleotide excision repair pathway removing DNA photoproducts induced by UV radiation. Genetic variation in XPD may exert a subtle effect on DNA repair capacity with an inverse association between the Lys751Gln and Asp312Asn polymorphisms and the risks of melanoma and squamous cell carcinoma (Han et al, 2005, Cancer Epidemiol Biomarkers Prev).

UVA-induced oxidative DNA damage and blocked DNA replication by UVB-induced photoproducts can lead to double-strand breaks (DSBs). DSB repair genes XRCC2, XRCC3, and LigaseIV were evaluated for their associations with skin cancer risk. (Han et al, 2004,Cancer Res). XRCC3 18085T (241Met) allele and its associated haplotype were significantly inversely associated with the risks of SCC and BCC (Han et al, 2004, Br J Cancer) The XRCC1 gene is also involved in the base excision repair pathway. The 399GIn allele was inversely associated with SCC risk in those who had five or more lifetime sunburns, those with a family history of skin cancer, and those in the highest tertile of cumulative sun exposure in a bathing suit (Han et al 2004, Cancer Res.). There was also a significant association of the carriage of 194Trp allele with increased SCC risk, which was modified by family history of skin cancer (Han et al, 2004, Cancer Epidemiol Biomarkers Prev).

In sporadic BCC, DNA repair capacity below the upper 30th percentile was associated with a 2.3 fold increase in BCC relative risk. However, some studies have reported increased repair in BCC patients and so batch variability and the effects of age, family history of skin cancer and current sun exposure may confound results (Hall et al 1994, Int J Cancer). At least two types of XP are caused by defects in DNA helicases that are involved in nucleotide excision repair and in transcription. Werner and Bloom syndromes are hereditary skin cancer disorders that are associated with helicase defects but curiously not with the development of BCC's (Yu Ce et al, 1996, Science, Ellis et al, 1995, Cell). Rothmund-Thomsen syndrome, which in some cases is caused by defects in a DNA helicase (Kitao et al, 1999, Nat Genet) does seem to predispose to BCC (Wang et al, 2001, Am J Med Genet). This tissue specific effect of helicases is poorly understood. Also, other forms of genomic instability disorders including the chromosome breakage disorders like ataxia telangiectasia and Nijmegen breakage syndrome and disorders with p53 gene mutations like Li Fraumeni syndrome (Malkin et al, 1990, Science) or dyskeratosis congenita, a disorder associated with failure to maintain telomeres (Knight et al, 1999, Am J Hum Genet, Vulliamy T, 2001, Nature) are not causally associated with BCC. 


\subsection{Chemical detoxication}

While exposure to UVR is accepted as a critical causative factor in the pathogenesis of BCC, the magnitude of the risk associated with increased exposure appears to be insufficiently large to explain the considerable phenotypic diversity demonstrated by patients in terms of tumour numbers, site and patterns of presentation.

UVA and UVB radiation cause indirect damage to DNA by inducing oxidative stress (Griffiths et al, 1998, Crit Rev Clin Lab Sci). Reactive oxygen species thus produced, interact with lipids, proteins and DNA to generate intermediates that combine with DNA to form adducts (Lear et al, 2000, Br J Dermatol).

The authors have focused on the extensive clinical diversity following initial presentation, demonstrated by patients to identify subgroups that are associated with different risks of developing tumours. Two phenotypes are particularly important; firstly, presentation with clusters of BCC. These patients, termed multiple presentation phenotypes (MPP), had 2-5 BCC at one presentation and comprised $15 \%$ of our study group of 1200 BCC patients. A minority of patients demonstrated multiple clustering events, a phenomenon that appears to be strongly associated with a genetic pre-disposition (Ramachandran et al, 1999, Cancer Epidemiol Biomarkers Prev; Ramachandran et al, 2000, Cancer).

The second risk phenotype, characterized by tumours on the trunk, is also associated with a pre-disposition. These patients are important as there is evidence that different mechanisms mediate development of BCC on this, compared with other sites. For example, patients whose first tumour was truncal had more BCC than other patients (mean 2.4 vs. 2.0 tumours), were significantly younger at first presentation and developed more clusters of BCC than cases who did not develop truncal tumours. First presentation with a truncal tumour is associated with significantly more subsequent BCC on this site compared with cases with an initial head and neck lesion (Ramachandran et al, 2001, Cancer). These data suggest the development of a truncal BCC is not random but rather is associated with a pre-disposition. In contrast, the rate of increase of non-truncal $\mathrm{BCC} /$ year was similar in patients with and without initial truncal lesions suggesting different mechanisms determine the development of truncal and non-truncal BCC (Ramachandran et al, 2001, Cancer).

Both the MPP and truncal phenotypes were characterized by a susceptibility to develop numerous BCC. All patients with more than 5 BCC had one or both of these phenotypes.

The GST supergene family offers protection against cytotoxic and mutagenic effects of electrophiles generated by UV induced oxidative stress. This is achieved by conjugation of glutathione to electrophiles. GSTM1 catalyses the conjugation of 4-hydroxynonenal and linoleic acid hydroperoxide, products of lipid peroxidation (Kerb et al, 1997, J Invest Dermatol). It also catalyses the conjugation of DNA hydroperoxide (Kerb et al, 1997,J Invest Dermatol), a product of DNA oxidation, 5 hydroxymethyluracil, a mutagenic compound formed by either oxidative attack on the methyl group of the thymine base of DNA or from deamination of products formed by the oxidation of 5-methylcytosine (Boorstein at al 1989, Nucleic Acids Res. Lear JT et al 2000,Br J Dermatol). The GSTM1 and GSTT1 have been shown to be associated with the development and accrual of basal cell carcinoma (Lear et al 1996, 1997, Carcinogenesis), raising the possibility of an association with SCC as well. Indeed, 
GSTM1 gene has been shown to be associated with actinic keratoses, supporting the possibility of its implication in SCC (Carless et al, 2002, J Invest Dermatol.).

The authors have examined the role of polymorphism in genes encoding detoxifying enzymes such as glutathione S-transferases (GST) and cytochrome P450s (CYP). The CYP supergene family comprise over 30 isoforms, which catalyse the biotransformation of a range of xenobiotics, often as the first of a two-phase detoxication. The resultant potentially highly reactive intermediate is then a substrate for phase two enzymes including members of the GST supergene family. The GSTs can also catalyse the detoxication of the products of oxidative stress (e.g. lipid and DNA hydroperoxides). Cytosolic GST activity in mammalian tissues is due to the presence of multiple GST isozymes, which can be assigned to 8 classes, e.g. $\alpha, \theta, \mu, \Pi \sigma, \kappa, \omega$ and $\zeta$ (Hayes et al, 1995, Crit Rev Biochem Mol). In human skin, the $\Pi$ class of GST is the predominant isozymes and is found predominantly in sebaceous glands (Raza et al, 1991, J Invest Dermatol). GST- $\Pi$ has been suggested to be an oncofetal protein that is expressed during carcinogenesis (Moscow et al, 1998, Proct Natl Acad Sci USA). Several polymorphisms in GST family members exist (Hayes et al, 1995, Crit Rev Biochem Mol Biol; Pemble, 1994,Biochem J) and have been associated with impaired detoxification, thus influencing the risk for several cancers, including non-melanoma skin cancer (Heagerty et al, 1994, Lancet; Heagerty, 1996, Br J Cancer).

A GSTT1 null genotype is associated with high UV sensitivity (Kerb et al, 1997 J Invest Dermatol) and we have shown that a GSTM1 null genotype also predisposes for BCC, probably due to its role in defence against UV induced oxidative stress (Learet al, 1997, Carcinogenesis; Lear, 1996,Carcinogenesis). Polymorphism of GSTM3 was also shown to increase the risk for multiple BCC (Yengi, 1996, Cancer Res). Polymorphism in cytochrome p450 CYP2D6 has also been associated with susceptibility as well as tumour numbers (together with vitamin D receptor and tumour necrosis factor alpha). In the case of multiple clustering, associations between the CYP2D6 EM genotype and risk demonstrated particularly large odds ratio (OR=15.5) (Ramachandran et al, 1999, Cancer Epidemiol Biomarkers Prev; Lear et al, 1996, Carcinogenesis).

\subsection{Immunological effects}

Though the role of UVR in the pathogenesis of skin tumours has been extensively studied, several reports have suggested that the resultant tumours are, at least in mice, highly immunogenic and regress on transfer to non-exposed hosts. This implies that the immune status of the UVR irradiated skin is compromised in those who develop tumours (Granstein, 1996, Photochem Photobiol). These findings are explained by data showing that exposure to UVR results in a cascade of events including a T-lymphocyte-mediated immunosuppression (Kripke, 1994, Cancer Res; Streilein 1993, J Invest Dermatol). The extent of the immunosuppression appears, to some degree, dose-dependent. Studies on the mechanism of this effect have concentrated on two chromophores; DNA and urocanic acid, both of which can result in altered expression of several cytokines including tumour necrosis factor alpha (TNF- $\alpha$ ), interleukin (IL-)10, IL-1 $\alpha / \beta$, IL-3, IL-6, IL-8, IL-10, granulocyte-macrophage colony-stimulating factor (GM-CSF) and nerve growth factor. This results in an alteration from a T helper 1 (Th1) to a suppressive T helper 2 (Th2) response (Granstein, 1996, Photochem Photobiol; Kripke, 1994, Cancer Res; Streilein 1993, J Invest Dermatol) thereby inhibiting the ability of antigen presenting cells to induce anti-tumour immunity. In a pilot 
study, we found in 133 patients with multiple BCC, the TNF allele haplotype a2b4d5 significantly influenced BCC number (mean BCC number; 8.1 vs. 3.7 in other allele combinations) (Hajeer et al, 2000, Br J Dermatol). Further support for the role of the immune system in the pathogenesis of skin cancer came from the finding that HLA-DR4 is associated with multiple BCC (Czarnecki et al, 1993, Dermatology) but this has been disputed (Rompel et al, 1995, Rec Res Canc Res). Interestingly, there is a possible link between GST and immune modulation in non-melanoma skin cancer with studies showing a link between contact hypersensitivity to dinitrochlorobenzene (a substrate for GST) and squamous cell carcinoma (and non-significantly with BCC) (de Berker, 1995, Lancet). Furthermore, GSTM1 and GSTT1 genotypes have been shown to influence inflammatory response following UVR exposure, a finding possibly reflecting the link between oxidative stress and eicosanoid mobilisation.

\subsection{Immunosuppression}

The critical role of immunomodulation in skin cancer susceptibility is further supported by data showing immunosuppressed transplant patients are at considerably higher risk of both BCC and SCC than the general population. SCC of the skin is the most common malignancy occurring in the setting of solid organ transplantation and immunosuppression, and its incidence increases substantially with the extended survival after transplantation (Otley et al, 2000, Liver Transpl). SCC occurs more frequently in transplant patients (Ondrus et al, 1999, Int Urol Nephrol) whereas in the general populations BCC is three to six times more frequent than SCC (Barrett et al, 1993, Cancer). It was shown in heart transplant recipients that the number of skin cancers is significantly correlated with both age at transplantation and duration of follow -up (Ong, 1999, J Am Acad Dermatol). In Europe, 40\% of renal transplant recipients develop skin cancer within 20 years after grafting, (Hartevelt et al, 1990, Transplantation). Heart transplant recipients are at a higher risk than kidney transplant recipients, most probably due to the fact that they receive higher doses of immunosuppression agents (Euvrard et al, 1995, J Am Acad Dermatol) but it cannot be overlooked that the different types of immunosuppressive agents have different effects in this respect. Immunosupression as practised after organ transplantation does not increase the risk of developing BCC to the same extent as SCC. The incidence of BCC seems not to be affected by PUVA treatment. A diminished response to skin application of dinitrochlorobenzene was found in people with SCC but not in patients with BCC, again supporting the notion that the incidence of BCC is not affected by immune status to the same extent as SCC (de Berker et al, 1995, Lancet).

\subsection{Human Immunodeficiency Virus}

People suffering from aquired immunodeficiency syndrome (AIDS) have shown an elevated risk for the development of BCC (Franceschi et al, 1998, Br J Cancer; Ragni et al, 1993, Blood). Human Immunodeficieny virus (HIV) patients with BCC more frequently show blue eyes, blonde hair, family history and extensive prior sun-exposure (Lobo et al, 1992, Arch Dermatol). The pigmentation phenotype is probably an independent risk factor that adds to the increased risk of BCC conferred by the immunosuppression. There have been some reports of BCC's metastasising in people suffering from AIDS, (Steigleder, 1987, Z Hautkr; Sitz, 1987, JAMA) suggesting that immune surveillance is one of the factors determining the normally metastatic nature of the BCC. Why immunosuppression by HIV increases the risk 
of BCC, where as pharmaceutical immunosuppression does not is not clear. The depletion of CD4 lymphocytes by HIV may lead to a more pervasive defect in adaptive antitumour immunity that does mere functional suppression by commonly used immunosuppressive compounds.

\subsection{Human Leukocyte Antigen (HLA) haplotypes}

The major histocompatibility complex (MHC) genes code for membrane protein that play important roles in controlling immune responses (Benacerraf, 1981, Science). There are two classes of genes, class I (HLA-A, -B, -C) and class II (HLA-DR, -DP and DQ) which play a role in host defence against the development and spread of tumours (Dausset et al, 1982, Cancer Surv). For example, loss of class 1 antigens is related to tumour progression in melanomas (Ruiter, 1984, Cancer Res). Furthermore, abnormalities in cell- mediated immunity have been reported in patients with multiple BCC (Myskowsky et al, 1981, J Am Acad Dermatol) whereas normal skin shows high levels of class 1 molecules, BCC shows either complete absence or heterogeneous expression (Cabrera et al, 1992, Immunobiol). All class I -negative tumours were histologically proven to be aggressive, whereas all nonaggressive BCC's were class I positive. The low levels or absence of expression of class I antigens may result in escape from recognition by cytotoxic $\mathrm{T}$ cells, which then facilitates tumour growth. (Garcia- Plata, 1991, Inv Met). The presence of HLA - DR7 and decrease of HLA-DR4 are significantly associated with BCC (Bouwes Bavinck, 2000, Arch Dermatol). HLA -DR4 is decreased in BCC, especially in patients with multiple BCC's located on the trunk (Rompel et al, 1995, Rec Res Canc Res,). HLA-DR1 is weakly associated with the development of multiple BCC's at an early age (Czarnecki et al, 1992, J Am Acad Dermatol). A correlation between HLA-A11 expression and skin cancer in immunosuppressed renal transplant recipients has been shown (Bavnick, 1990, N Engl J Med; Bouwes Bavnick, 1997, Australia J Invest Dermatol). One study showed that HLA -A11 was associated with resistance to skin cancer in renal transplant recipients, (Bavnick, 1990, N Engl J Med) while another study shows that renal transplant recipients with HLA - A11 had an increased risk for developing skin cancer (Bouwes Bavnick, 1997, Australia J Invest Dermatol). The apparent discrepancy may be the result of different genetic backgrounds and differential environmental factors.

\subsection{Human Papilloma Virus}

The life cycle of these species-specific DNA tumour viruses is inseparably linked to differentiation processes in pluristratified epithelia (Stanley et al, 1994, Ciba Found Symp). Mucosal HPV types 16, 18, 31 and 33 are strongly associated with the genesis of anogenital and cervical carcinomas (Bosch et al, 2002, J Clin Pathol). Following viral genome integration, E6 and E7 oncoproteins are overexpressed, with inhibition of apoptosis via p53 dependent and independent mechanisms (Thomas et al, 1999, Oncogene). E6 protein from the cervical associated HPC-16 mediates degradation of p53 (Black et al, 2003,Clin Exp Immunol). A common p53 polymorphism at position 72 replacing proline with arginine renders p53 more susceptible to E6 mediated degradation. The arginine allele was found to be a risk factor in the development of cervical cancers and there was also a significant association with cutaneous SCC development in renal transplant patients (Storey et al, 1998, Nature).

Cutaneous HPV types 5 and 8 are associated with warty lesions and SCC in the sun exposed sites of patients with the rare inherited condition epidermodysplasia verruciformis. This led 
to the proposal that these EV types may also be oncogenic. (Majewski et al, 1995, Arch Dermatol ). The mechanism by which EV associated HPV might contribute to the development of SCC remains unclear. Unlike oncogenic mucosal HPV, EV-HPV DNA persist extrachromosomally in cancers and EV associated E6 proteins are unable to abrogate apoptosis via the degradation of p53. (Elbel et al, 1997,Virology) Instead, BAK protein, a member of the Bcl- 2 family may be abrogated resulting in inhibition of apoptosis (Jackson et al 2000, Genes Dev).

HPV DNA has been identified in over $80 \%$ of immunosuppressed and $30 \%$ of immunocompetent SCC patients and EV-HPV types are consistently overexpressed in immunosuppressed patients. (Harwood et al, 2002, Curr Opin Infect Dis, Pfister et al 2003, J Natl Cancer Inst Monogr.) The association between prevalence of EV-HPV infection and SCC risk has been further strengthened by seroepidemiological studies (Bouwes Bavinck et al 2000, Br J Dermatol., Feltkamp et al, 2003, Cancer Res. Masini et al 2003,Arch Dermatol.). Furthermore, localisation of HPV DNA to malignant keratinocytes in SCC as well as EVHPV gene transcription in almost $40 \%$ of tumours has been found by in situ hybridisation technique, thus providing further evidence of the role of HPV in pathogenesis of SCC (Purdie et al 2005, J Invest Dermatol.). The presence of UV induced p53 mutations in cutaneous SCC contrasts with tumours induced by high-risk HPV types, which contain wild type p53. It is postulated that arginine allele of p53, perhaps in combination with UV induced mutation, is more susceptible to interference from particular HPV types and subsequent malignant transformation (Black et al, 2003,Clin Exp Immunol). HPV 77 has so far been detected in cutaneous lesions of renal transplant patients and contains a p53 DNA binding site. Besides inducing p53 mutations, sunlight may also be indirectly involved in the pathogenesis of SCC by causing activation of p53 and subsequent stimulation of HPV 77 promoter activity (Purdie et al, 1999, EMBO J.). Other viruses suggested to increase susceptibility to SCC include HPV 20, HPV 27 (Ruhland et al 2001,Int J Cancer.) and human herpes virus type 1 (Leite et al 2005, Cancer Lett.).Although HPV has been associated strongly with malignant progression of warts to SCC and with epidermodysplasia verruciformis, (Galloway et al, 1989, Adv Virus Res) different oncogenic subtypes of the virus were found in $60 \%$ of BCC's from immunosuppressed patients in contrast to $36 \%$ of BCC's from non-immunosuppressed patients, suggesting that these viruses may be involved in the development of BCC (Shamanin et al, 1996, J Natl Cancer Inst). In renal transplant recipients with skin cancer, HPV 5 /8 DNA could be detected, (Barr et al, 1989, Lancet) and Weinstock et al (Weinstock et al, 1995, Arch Dermatol) suggested immunosuppression to be a factor in BCC carcinogenesis by affecting HPV infection.

\subsection{Delayed hypersensitivity}

Patients with large SCC were found to have defective systemic cell-mediated immunity as shown by reduced reaction to intradermal antigen, and low rate of sensitization to dinitrochlorobenzene (DNCB) (Weimar et al 1980, J Am Acad Dermatol.). Because GST metabolises DNCB and polymorphisms of GST are associated with multiple skin tumours, variations in GST may underlie these differences (de Berker et al, 1995, Lancet). The T cell levels and leukocyte migration test in preoperative patients with SCC were also found to be significantly lower than in the noncancer control population. (Avgerinou et al, 1985, Dermatologica.) 


\section{Germline and somatic mutations}

Carcinogenesis involves a stepwise progression from a normal to a malignant phenotype through an accumulation of genetic alterations to cellular proto-oncogenes, that stimulate cell proliferation and tumour suppressor genes (TSG) that inhibit this process. In tumours, mutation of proto-oncogenes results in expression of constitutively active proteins, whereas mutational inactivation of TSG leads to loss of protein function.

\section{$4.1 \mathrm{p} 53$}

p53 is a TSE that normally functions in cell-cycle arrest, DNA repair and apoptosis. It functions as a critical regulator of the cell cycle progression and programmed cell death in response to insults that damage DNA, such as UVR exposure (Natraj, 1995, Photochem Photobiol.). The p-53 gene encodes a phosphoprotein that is involved in cell-cycle control and maintenance of chromosomal stability (Katayama 2004, Nat Genet; Hollstein M, 1991, Science). The most common genetic aberrations in human skin cancers are found the level of p53 gene expression (Kastan, 1991, Cancer Res). DNA strand breaks results in expression of p-53, which in turn stimulates p21 Cip1 expression, which binds and inhibits cyclindependent kinases 2 and 4 resulting in G1 blockade of cell cycle progression. This inhibition of cell cycle progression allows for DNA repair before it is replicated in S phase to prevent retention of introduced mutations. In severe DNA damage, p53 induces BAX, which binds to BCL-2 and inhibits its antiapoptotic activity, resulting in programmed cell death. Thus, mutations would be retained in genomic DNA if p53 gene becomes inactivated, leading to clonal expansion and tumourigenesis.

p53 gets activated in response to cellular stress through phosphorylation (Siliciano et al, 1997, Genes Dev, Caspari, 2000, Curr Biol). MDM2 associates with p53 and regulated its level of activity depending on the phosphorylation status of p53. Upon dephosphorylation, p53 binds to MDM2 and is degraded through the ubiquitin-proteasome pathway (Kubbutat et al, 1997, Nature, Haupt et al, 1997, Nature)

The response to DNA damage is growth, senescence or apoptosis (Vogt Sionov et al, 1999, Oncogene). The relative cellular content of p53 determines the response following DNA damage; when the content is low to moderate, cells will go into cell- cycle arrest to allow DNA repair, but when p53 levels are high, cells will progress to apoptosis (Ronen et al, 1996, Cell Growth Different). In response to DNA damage, p53 is phosphorylated by DNA damagesensing proteins such as ATM and becomes detached from MDM2, resulting in stabilization and activation and of target genes regulated by p53 (Unger et al, 1999, EMBO J). In normal skin, wild type p53 is not detectable but appears within 2 hours after UV irradiation, with peak levels at 24 hours and again undetectable levels at 36 hours (Hall et al, 1993, Oncogene). Mutant p53 can accumulate in cells and p53 mutations have been detected in about half of all BCCs (Aeupemkiate et al, 2002, Histopathology, Demirkan et al, 2000, Pathol Oncol Res). Aggressive BCC are significantly associated with increased p53 expression, probably representing the mutated form. Despite the available evidence, the apparent limited contribution of DNA damage and chromosomal instability to the BCC phenotype means that the relevance of p53 mutations for BCC growth remains to be demonstrated as in the absence of genetic damage p53 activation does not occur. Moreover, one of the hallmarks of 
p53 dysfunction, aberrant mitosis, has never been observed in BCC (Pritchard, 1993, Am J Dermatopathol).

Patients with BCC, who were sunscreen users, had significantly lower level of p53 mutations in their BCC as compared to non-sunscreen users (Rosenstein el al, 1999,Photochem Photobiol) suggesting that p53 mutations in BCC are secondary events. Inactivation of p53 occurs predominantly by point mutation of one of the allele followed by loss of the remaining wild type allele (Knudson et al, 1985, Cancer Res). The p53 gene shows UV signature mutation, i.e. predominantly $\mathrm{C}(\mathrm{C}) \rightarrow \mathrm{T}(\mathrm{T})$ conversions (Ziegler et al, 1993, Proct Natl Acad Sci USA, Wikonkal et al, 1999, J Invest Dermatol Symp Proc). In 33\% of BCCs found in Korean patients, p53 mutations were detected (Kim, 2002, J Dermatol Sci) and up to 50\% of the BCCs in Caucasian patients showed this mutation (Aeupemkiate et al, 2002, Histopathology, Demirkan, 2000, Pathol Oncol Res), suggesting that different ethnic factors play a role in BCC carcinogenesis, although differences in sun exposure may account for some of the observed differences.

Thus, while it is known that $p 53$ is involved in genome surveillance through the regulation of cell proliferation and death and is frequently inactivated in BCC (Rady et al, 1992 Cancer Res, Ziegler et al, 1993, Proct Natl Acad Sci USA), with up to $56 \%$ of tumours displaying mutation in the conserved region of one $p 53$ allele, it has been suggested that $p 53$ mutation is a crucial but late event in BCC progression (Van der Riet et al, 1994, Cancer Res). BCC also display a high level of LOH specifically at chromosome 9q22 suggesting the existence of a BCC TSG in this region (Quinn et al, 1994, Cancer Res).

Up to $90 \%$ of cutaneous SCC lesions have UV induced signature mutations such as formation of thymidine dimers in the p53 gene, resulting in uncontrolled proliferation of keratinocytes (Brash et al, 1991, Proc Natl Acad Sci U S A, Ziegler, 1994, Nature). Overexpression of p53 co-relates with sun-exposure (Coulter et al 1995, Hum Pathol. Liang, 1999, Virchows Arch.) and mutant p53 has been observed to accumulate in the cell cytoplasm, probably due to increased half-life of the protein (Dowell et al 1994, Cancer Res, Soussi , 2000, Ann N Y Acad Sci. ). Indeed, sunlight- induced mutations are found in p53 in actinic keratoses, the precancerous lesion of for SCC. In addition, it has been shown that mutations at particular p53 codons are present in sun exposed normal human skin and UV irradiated mouse skin (Ziegler et al, 1994, Nature. Nakazawa et al, 1994, Natl Acad Sci U SA, Jonason et al, 1996, Proc Natl Acad Sci U S A.)

Sunlight has been shown to be a tumorigenic mutagen and tumour promoter by favouring the clonal expansion of p53 mutated cells. The role of UV in carcinogenesis is also supported by the observation that most human precancers (Marks et al, 1986, Br J Dermatol.) and UV induced clusters of p53 overexpressing cells in mouse skin (Berg et al 1996, Proc Natl Acad Sci U S A ) regress in the absence of continued exposure. The dermal-epidermal junction and hair follicles are the locations of the presumed stem cells in skin (Lavker et al 1993, Recent Results Cancer Res.) and appear to be the source of tumours in experimental animals (Miller et al,1993, J Invest Dermatol.). It is therefore thought that normal sun exposed skin carries a substantial burden of keratinocyes predisposed to cancer (Jonason et al, 1996, Proc Natl Acad Sci U S A.). The ubiquitin proteasome pathway rapidly degrades wild type p53 in normal tissue (Maki et al 1996, Cancer Res.). Thus, high level of p53 expression is seen in 
cutaneous SCC and other tumours in contrast to the low levels found in non-malignant tissue.

Clonal expansion of p53 mutated cell would be favoured if a p53 mutation confers resistance to apoptosis resulting from UV exposure (Ziegler A, 1994,Nature). Such resistance would allow sunlight to act as tumour promoter by killing normal cells and sparing the mutants (Ziegler A, 1994,Nature.). After surviving irradiation, these mutant cells could then clonally expand into vacated compartments (Jonason et al, 1996,Proc Natl Acad Sci U S A.).

\section{2 p63}

p63 is a p53 homologue that is mapped to chromosome $3 q 27$. This gene encodes six different isoforms, which have either transactivating or dominant negative effects on p53-reporter genes. p63 is a reliable keratinocyte stem cell marker involved in the maintenance of the stem cell population. It is expressed in the nuclei of epidermal basal and suprabasal cells, cells of the germinative hair matrix and the external root sheath of hair follicles, basal cells of the sebaceous gland and in the myoepithelial / basal cells of the sweat glands. p63 has a nucleoplasmic distribution in the basal compartment of stratified epithelia such as skin, tonsil, bladder, and certain subpopulations of basal cells in prostate, breast, uterine cervix and bronchi (Wang et al, 2001, Hum Pathol; Quade et al, 2001, Gynaecol Onco; Di Como et al, 2002, Clin Cancer Res). All terminally differentiated cells stain negative for p63. The p63 is restricted to cells with high proliferation and absent from cells undergoing terminal differentiation (Parsa et al, 1999, J Invest Dermatol). p63-deficient mice have striking developmental defects such as absence or truncation of limbs, absence of hair follicles, teeth and mammary glands, and the skin lacks stratification and differentiation (Mills et al, 1999, Nature). This indicates that p63 is essential for several aspects of differentiation during embryogenesis. Several isoforms of p63 can bind to p53 consensus sequences and activate p53 target genes. p63 is only rarely mutated in BCC ( Little et al. , 2002, Int J Biochem Cell Biol ). p63 functions not only as a stem cell marker of keratinocytes but also maintain the stem cell phenotype. In keeping with its basal localisation in normal epidermis, BCC cells express p63 (Di Como et al, 2002, Clin Cancer Res, Dellavale et al, 2002, Exp Dermatol). It was shown that aberrant expression of p63 altered the UVB induced apoptotic pathway that down regulation of this protein in the response to UV irradiation is important in epidermal apoptosis (Liefer et al, 2000, Cancer Res).

Although it has been described that in contrast to p53, p63 seems not to be associated with tumor predisposition, as neither p63 knockout mouse models nor germline p63 mutations are related to an increased risk of tumourigenesis; its role in the pathogenesis of SCC is becoming more convincing. Using immunohistochemistry techniques undifferentiated cells of grade III SCCs showed strong positivity for p63 (Reis-Filho et al 2002, J Cutan Pathol.). The SCCs in situ showed remarkable expression of p63 in all cell layers. Terminally differentiated squamous cells were either negative or showed only focal immunoreactivity in the carcinomas. p63 is consistently expressed in the basal cells of epidermis and cutaneous appendages, including the basal/myoepithelial cells of sweat glands. These probabilities favour that p63 might play a role in the pattern of differentiation and in the oncogenesis of usual carcinomas of the skin (Reis-Filho et al 2002, J Cutan Pathol.). 


\subsection{PTCH}

A major breakthrough in understanding BCC tumourigenesis came from the study of patients with Nevoid Basal Cell Carcinoma Syndrome (NBCCS) an autosomal dominant disease whose symptoms include developmental abnormalities and a predisposition to multiple BCC. The disease is linked to chromosome 9q22, which harbours the PTCH gene where inactivating germline mutations have been found in these patients (Hahn et al, 1996, Cell; Johnson et al, 1996, Science). Somatic PTCH mutation has also been described in sporadic BCC (Azsterbaum et al, 1998, J Invest Dermatol, Gailani et al. 1996, Nat Genet). In accordance with a tumour suppressor mechanism for $\mathrm{PTCH}$, loss of the wild type allele has been demonstrated in BCC from both NBCCS patients and in up to $68 \%$ of sporadic BCC (Gailani et al. 1996, Nat Genet).

Although most SCC carry a mutation in the p53 gene, they have also been shown to display PTCH mutations (Ping et al, 2001,J Invest Dermatol.) and allelic loss of PTCH gene (Ahmadian et al 1998,Oncogene.) and an increased incidence of SCC has been observed in UV irradiated heterogeneous PTCH knock out mice (Aszterbaum et al, 1999, Nat Med). The introduction of wild-type PTCH into human SCC lines that express mutant PTCH has been shown to suppress their oncogenic potential (Koike et al 2002, Oncogene). These finding implicate the role of PTCH in development of SCC in addition to its established association with the development of BCC (Asplund et al 2005, Br J Dermatol.) However, the association between PTCH and cutaneous SCC development remains controversial as a previous investigation of the PTCH status in cutaneous SCC failed to identify mutations on such cases (Eklund et al 1998, Mol Carcinog). Consistently, PTCH LOH has not been found to be as frequent in SCC, indicating a lesser importance of PTCH gene in SCC development (Asplund et al 2005, Br J Dermatol.)

\subsection{Hedegehog signalling and BCC development}

PTCH is the human homologue of the Drosophila patched (ptc) gene which encodes Ptc protein. Ptc a part of a receptor for the diffusible morphagen Hedgehog (Hh). In Drospophila $\mathrm{Hh}$ signalling is essential for the control of segment polarity during development. Hh is expressed in the Hensen node, the floorplate of the neural tube, the early gut endoderm, the posterior limb buds and throughout the notochord, and encodes a signal responsible for patterning the early embryo (Kim et al, 2002, J Dermatol Sci, Bodak et al, 1999, Proc Natl Acad Sci USA, Bale et al, 2001, Hum Mol Genet).

Ptc negatively regulates $\mathrm{Hh}$ signalling through inhibition of a transmembrane signalling protein Smoothened (Smo). There is some evidence that Ptc may influence the localisation or intramembrane conformation of Smo (Sprong et al, 2001, Nat Rev Mol Cell Biol). Binding of $\mathrm{Hh}$ to Ptc releases Smo inhibition leading to intracellular signalling involving Costal-2, Fused and Suppressor of Fused proteins (Stone et al, 1999, J Cell Sci). This leads to activation of GSK3 $\beta$ which stimulated the release of a transcription factor Cubitus interrruptus (Ci) that regulates the expression of important genes involved in Drosophila cell proliferation including $d p p$, wingless and $p t c$. The Hh signalling pathway is highly conserved, where it is involved in determining cell fate and organogenesis in different species including humans (Wicking et al, 1999, Oncogene). 
In humans, it is thought that signalling operates in a similar fashion to that described in Drosophila. To date, disrupted expression of the human homologues of Hh (sonic hedgehog; $\mathrm{SHH}), \mathrm{Ptc}$ (PTCH and PTCH2), Smo (SMOH) and $\mathrm{Ci}$ (GLI) have been demonstrated in BCC tumourigenesis. Overexpression of $\mathrm{SHH}$ in transgenic human skin induces features of BCC in mice (Fan, 1997, Nat Med, Oro et al, 1997, Science). Furthermore, SHH activating mutations have also been described in sporadic BCC (Oreo et al, 1997, Science). SMOH and GLI transgenic activation in mice leads to BCC-like cutaneous growths (Xie et al, 1998, Nature, Nilsson et al 2000 Proc Natl Acad Sci. USA). SMOH, GLI-1 and GLI-2 are frequently over expressed in BCC and $S M O H$ activating mutations have also been described in $20 \%$ of sporadic BCC's (Xie et al 1998, Nature; Kallassy, 1997 Cancer Res; Dahmane 1997, Nature; Grachtchou, 2000, Nature Genet ). The consequences of deregulated Hh signalling are widespread, as the downstream targets of GLI transcription factors include WNT signalling (human homologue of wingless), TGF $\beta$ (homologue of dpp) BMP2B and BCL-2 (Fan, 1997, Nature Med) and may also influence cell cycle control genes including $p 21^{\text {WAF1 }}$ the D-type cyclins and cyclin E (Fan, 1999, J Cell Biol; Duman-Scheel, 2002, Nature).

\subsection{Melanocortin-1 receptor genotype}

As pigmentation influences NMSC risk, the identification of gene variants at the melanocortin-1 receptor (MC1R), which control the production of red pigmentation in Caucasian individuals, suggest that the allelic variation within this gene should likewise be associated with skin cancer risk (Box et al 2001,J Invest Dermatol.) Indeed, gene variations at this locus are important in determining susceptibility to melanoma, BCC, SCC and solar keratoses (Box et al 2001, J Invest Dermatol.). The association between MC1R variants and the propensity to develop solar lesions is mediated largely through three variants, Arg151Cys, Arg160Trp, and Arg294His, which are also associated with red hair, fair skin colour and tanning ability (Box et al 2001,J Invest Dermatol.).

\subsection{RAS mutations}

Although the role of TSG in the development of SCC is well established, evidence relating to the role of dominantly transforming oncogenes in the development of skin cancers is slow to emerge. Activating RAS mutations are the most common genetic abnormalities in human cancers. Following RAS mutation, MAPK mediated signalling and other pathways are activated, resulting in cell proliferation (Shields, 2000, Trends Cell Biol.). Activation of RAS oncogenes usually occurs by point mutations within specific codons of the H-RAS, N-RAS, and K-RAS genes. Activating H-RAS mutations were observed in $35 \%$ to $46 \%$ of SCC (Kreimer-Erlacher, 2001, Photochem Photobiol., Pierceall, 1991,Mol Carcinog.) and 12\% of actinic keratoses (Spencer et al, 1995,Arch Dermatol.). Incidences and numbers of skin tumors were much greater in Hras128 rats (a transgenic rat line carrying 3 copies of the human c-Ha-ras proto-oncogene with its own promoter region) than in their wild-type counterparts (Park el al, 2004, Cancer Sci.)

These data suggest that RAS mutations play an important role in the pathogenesis of SCC.

\subsection{CDKN2A}

The p16(INK4a) and p14(ARF) TSGs are encoded within the CDKN2A locus on chromosome 9p21 and function as cell cycle regulatory proteins in the p53 and RB 
pathways. Loss of heterozygosity of 9p21 markers has been seen in some cases of SCC (Brown et al 2004). Mutational analysis has confirmed point mutations that changed the amino acid sequence of p16 (INK4a) and p14 (ARF). Promoter methylation of p16 (INK4a) and p14 (ARF) has also been detected. Absent protein expression was has been confirmed by immunohistochemistry in SCC with biallelic inactivating events. Overall, promoter methylation is the commonest mechanism of gene inactivation. Alterations at this locus are significantly more common in tumors from immunocompetent compared with immunosuppressed individuals (Brown et al 2004, J Invest Dermatol.). UV radiationinduced mutations in INK4a-ARF have been demonstrated in XP-associated skin carcinomas. The simultaneous inactivation of p53 and INK4a-ARF may be linked to the genetic instability caused by XP and could be advantageous for tumour progression.

\subsection{Progression and initiation of BCC}

Exposure to UVR is significant in BCC formation and this is reflected in the $p 53$ mutations identified; C-T and CC-TT transitions at di-pyrimidine sites. A third of the BCC displaying $\mathrm{LOH}$ at $9 \mathrm{q}$ reveal mutations to $\mathrm{PTCH}$ indicative of UVR exposure. However, most mutations to $\mathrm{PTCH}$ are not typical of exposure. Further, inactivation of the second $\mathrm{PTCH}$ allele through LOH is unlikely to be due to UVB (Gailani et al, 1996, J Natl Cancer Inst). In addition, ptc heterozygous knockout mice $\left(p t c / p t c^{-}\right)$display features of NBCCs syndrome, these mice develop microscopic follicular neoplasms similar to trichoblastoma and $40 \%$ subsequently develop BCC. If exposed to ionising or UVR irradiation these neoplasms occur at a much earlier stage and there is a clear shift in histological features to BCC (Aszterbaum et al, 1999, Nature Med). Thus, whilst UVR exposure is critical to SCC development, it appears that in BCC, UVR exposure may be more important in modifying tumour progression. Further characterisation of the role of the Hh signalling pathway should provide new insights into BCC carcinogenesis. Identifying the mutations to these BCC genes and the relationship of these mutations to environmental carcinogens may explain the variation in phenotype of sporadic BCC. It is possible that mutations manifest different phenotypic effects depending on the genetic background of the patient (e.g. skin type, hair colour, GST genotype). Whilst gene mutation influences tumour development, we can speculate that inter-individual variation in genes that protect against exposure to environmental carcinogens may modify the effects of exposure to mutation in these target genes. Thus, we have found an increase in the incidence of tumour specific p53 mutation and expression in ovarian cancer patients with GSTM1 null genotype (Sarhanis et al 1996, Br J Cancer). In addition, CYP3A and CYP2D6 activities and the GSTM1 null genotype have been associated with mutations to $p 53$ and $R B$ and are associated with aggressiveness in bladder carcinoma (Romkes et al, 1996, Carcinogenesis).

\section{Pharmacogenomics}

As discussed above, UV radiation induced oxidative stress and mutagenic DNA lesions formed by reactive oxygen species (ROS) are pivotal in the pathogenesis of SCC. Clinical treatments inducing chronic oxidative stress may therefore carry a risk of therapy-related cancer. Immunosuppression by azathioprine (Aza) has been proposed as one such treatment. Biologically relevant doses of ultraviolet A (UVA) generate ROS in cultured cells 
with 6-thioguanine substituted DNA and 6-thioguanine and UVA are synergistically mutagenic (O'Donovan et al, 2005, Science.).

Kidney transplant recipients receiving cyclosporine, azathioprine, and prednisolone have a significantly (2.8 times) higher risk of cutaneous SCC relative to those receiving azathioprine and prednisolone alone (Jensen et al, 1999, Am Acad Dermatol) suggesting a tumourigenic role of cyclosporine based immunosuppressive therapy. Both cyclosporine and ascomycin inhibit removal of cyclobutane pyrimidine dimers, and UVB-induced apoptosis (Yarosh et al, 2005, J Invest Dermatol.). UVB induces nuclear localization of the transcription factor nuclear factor of activated T-cells (NFAT), a process blocked by cyclosporine and ascomycin (Yarosh et al, 2005, J Invest Dermatol. ) These data suggest that the increased risk of skin cancer observed in organ-transplant patients may be as a result of not only systemic immune suppression but also the local inhibition of DNA repair and apoptosis in skin by calcineurin inhibitors(Yarosh DB et al, 2005, J Invest Dermatol.)

Thus, cancer is an increasingly recognized problem associated with immunosuppression. However, in contrast to cyclosporine which protects allografts from rejection but promotes cancer progression in transplant recipients, immunosuppressive agent rapamycin has been found to simultaneously protect allografts from rejection and attacks tumors in a complex transplant-tumor situation (Koehl et al, 2004,Transplantation.). In vitro experiments have shown that cyclosporine promotes angiogenesis by a transforming growth factor-betarelated mechanism, and that this effect is abrogated by rapamycin (Koehl et al, 2004, Transplantation.). Various surgical and non- surgical therapies are available for the treatment of BCC (Albright et al, 1982, J Am Acad Dermatol). In spite of the fact that surgical excision is still the most prominent therapy used, non -invasive therapies such as photodynamic therapy (PDT) (Thissen et al, 2000, Br J Dermatol), or topical application of 5fluorouracil (5-FU) (Miller, 1997, J Am Acad Dermatol) are currently becoming more and more interesting in selective cases, especially because of the improved cosmetic outcome.

\subsection{Induction of apoptosis}

Many currently used antineoplastic agents exert their therapeutic effects through the induction of apoptosis. Different cell types vary profoundly in their susceptibility, suggesting the existence of distinct cellular thresholds for apoptosis induction (Fisher, 1994, Cell). For example, BCC cells overexpressing IL-6 are resistant to UV irradiation and PDT induced apoptosis (Jee et al, 2001, Oncogene). de novo p53 synthesis or stabilisation of p-53 is essential to induce apoptosis in BCC ( Jee et al, 1998, J Invest Dermatol). Overexpression of the antiapoptotic bcl-2 has also been linked to resistance of cancers to various chemotherapeutic drugs (Huang, 2000, Oncogene). In BCC, interferon (IFN)-a induces apoptosis and is thus effective in the treatment (Rodriguez-Villanueva et al, 1995, Int J Cancer). Untreated BCC cells express FasL but not the receptor, but in IFN-a - treated BCC patients, the tumour cells express both FasL and receptor, whereas the peritumoural infiltrate mainly consists of Fasreceptor- positive cells (Buechner, et al, 1997, J Clin Invest). Therefore, with IFN- a treatment, BCC most likely regress through apoptosis.

The regression of tumours treated with 5-FU is probably caused by enhancing apoptosis in the tumour cells (Brash, 1998, Cancer Surveys). Apoptosis is involved in the regression of 
actinic keratoses after PDT (Nakaseko et al, 2003, Br J Dermatol).This therapy is also used for treatment of BCC, (Kalka, 2000, J Am Acad Dermatol), where tumour cells may also undergo apoptosis.

Phytochemicals known to induce apoptosis are also being applied in cancer prevention and therapy (Hoffman et al, 1999, Cancer and the search for selective biochemical inhibitors, CRC Press). In mice bearing skin tumours, tumour growth was inhibited by $70 \%$ after treatment with black tea, which was established by inhibition of proliferation and enhanced apoptosis ( $L u$ et al, 1997, Carcinogenesis). Ajone, an organosulphur compound of garlic (Apitz-Castro et al, 1988, Arznei-Mittelforschung) has been shown to induce apoptosis in human promyeloleukaemic cells (Dirsch, 1998, Mol-Pharmacol). Recently, it was shown that ajone can induce apoptosis in the human keratinocyte cell line HaCat and has a diminishing on $\mathrm{BCC}$ in vivo by down-regulating the expression of the apoptosis- suppressing protein Bcl-2 (Tilli et al, 2003, Arch Dermatol-Res). A SHH antagonist, the Veratrum alkaloid cyclopamine (11-deoxojervine) can be used to treat BCC (Taipale et al, 2000, Nature). Interestingly cyclopamine binds directly to Smoothened, which explains its activity in tumours characterised by activated SHH pathways (Chen et al, 2002, Proc Natl Acad Sci USA). Interestingly its application to the surface of the tumour resulted not only in the rapid induction of apoptosis but also influenced the differentiation status 7 of 7 tumours (Tas et al, 2004, Eur J Dermatol)

\subsection{Modulation of differentiation}

Systemic retinoids are frequently used for chemoprevention of cutaneous malignancies in organ transplant recipients (Chen et al, 2005, Br J Dermatol.). Retinoids (vitamin A metabolites and analogues) have been shown to have suppressive effects on tumour promotion when administered in high doses, and the mechanism appears to be associated with modulation of growth, differentiation and apoptosis (Lotan et al, 1996, Faseb J). Retinoids are most effective in patients with multiple previous non-melanoma skin cancers (Kovach et al, 2005,Clin Transplant.) Low-dose systemic retinoids significantly reduce SCC development in organ transplant recipients for the first 3 years of treatment, and this effect may be sustained for at least 8 years (Harwood et al, 2005, Arch Dermatol.) It has been shown that retinoic acid is effective in inhibiting telomerase activity in HSC-1 human cutaneous squamous cell carcinoma cells (Kunisada et al, 2005,Br J Dermatol. ).

\subsection{Immunomodulation}

Because BCCs often elicit a strong inflammatory response, recent studies have sought to evaluate the effects of immunomodulatory compounds. On of the most promising is imiquimod, a Toll- like receptor $7 / 8$ agonist that enhances the endogenous cytokine response (INF- $\alpha$, IL-10, TNF- $\alpha$ ) among others stimulating the T- helper 1 - mediated inflammatory responses.

\section{Conclusions/ future directions}

In the past decade, significant progress has been made, in understanding the molecular genetics of NMSC and the molecular pathways involving tumour suppressor genes and 
oncogenes. Research into immune response to p53 had led to promising therapeutic potential. p53-specific cytotoxic T lymphocytes capable of mediating protective immunity to tumours have been generated in murine models (Black et al, 2003,Clin Exp Immunol.). Adoptive transfer of p53 specific cytotoxic T lymphocytes generated in p53-/- mice confers immunity on the recipient to p53 overexpressing murine tumour (Vierboom et al, 1997,J Exp Med.). As p53 is over expressed in cutaneous SCC, vaccination against p53 is a logical approach to induce tumour reactive immunity (Black et al , 2003,Clin Exp Immunol.) Vaccines used to induce p53 specific immune responses in mice have included, Canary pox virus vectors (Roth et al, 1996,Proc Natl Acad Sci U S A.), peptide pulsed dendritic cells (Mayordomo et al, 1996, J Exp Med. ), recombinant adenovirus transduced dendritic cells (Ishida et al, 1999, Clin Exp Immunol., Nikitina, 2002,Gene Ther.), recombinant DNA, (Petersen et al, 1999, Cancer Lett.) recombinant vaccinia virus (Chen et al, 2000, Cancer Gene Ther. ) and pulsed human monocyte-derived dendritic cells (Tokunaga et al, 2005,Clin Cancer Res.). However, besides p53, many genes are involved in the pathogenesis of SCC and an understanding into the genomic of SCC is far from complete. It is very likely that new genetic and molecular pathways for SCC genesis will unravel in the future, hopefully leading to novel therapies.

Clearly exposure to UVR is an important initiating factor in skin cancer, though the exact relationship between $\mathrm{BCC}$ risk and nature, extent and timing of exposure remains poorly understood. More recently, the influence of genetic factors influencing BCC susceptibility has been an area of intense interest with many genes having a similar impact as traditional risk factors such as skin type. Data so far suggests that risk of sporadic BCC is likely to result from the combined effect of many genes (defining distinct areas of biochemical activity) each with a relatively weak individual contribution, rather than a small number of highly influential genes.

Presumably, the effect of disruption of these biochemical activities will result in dysregulation of expression of key TSG or oncogenes. In this regard, the function of the hedgehog signalling pathway appears critical in BCC development. Though the PTCH gene has been suggested to be the 'gatekeeper' for BCC development, future studies will need to address the role of other members of this pathway. There are no studies to date focusing on the interaction between susceptibility genes and mutational events in TSG in BCC; this may represent a way forward.

\section{References}

[1] Ahmadian A, Ren ZP, Williams C et al. Genetic instability in the 9q22.3 region is a late event in the development of squamous cell carcinoma. Oncogene. 1998 Oct 8;17(14):1837-43.

[2] Albright SD 3rd. Treatment of skin cancer using multiple modalities. J Am Acad Dermatol. 1982 Aug;7(2):143-71

[3] Apitz-Castro R, Ledezma E, Escalante J et al. Reversible prevention of platelet activation by (E,Z)-4,5,9-trithiadodeca-1,6,11-triene 9-oxide (ajoene) in dogs under extracorporeal circulation. Arzneimittelforschung. 1988 Jul;38(7):901-4. 
[4] Arbiser JL, Fine JD, Murrell D et al. Basic fibroblast growth factor: a missing link between collagen VII, increased collagenase, and squamous cell carcinoma in recessive dystrophic epidermolysis bullosa. Mol Med. 1998 Mar;4(3):191-5.

[5] Arbiser JL, Fan CY, Su X et al.Involvement of p53 and p16 tumor suppressor genes in recessive dystrophic epidermolysis bullosa-associated squamous cell carcinoma. $J$ Invest Dermatol. 2004 Oct;123(4):788-90.

[6] Asplund A, Gustafsson AC, Wikonkal NM et al. PTCH codon 1315 polymorphism and risk for nonmelanoma skin cancer. Br J Dermatol. 2005 May;152(5):868-73.

[7] Aszterbaum M, Rothman A, Johnson RL et al. Identification of mutations in the human PATCHED gene in sporadic basal cell carcinomas and in patients with the basal cell nevus syndrome. J Invest Dermatol. 1998 Jun;110(6):885-8.

[8] AszterbaumM, EpsteinJ, OroA etal. Ultraviolet and ionizing radiation enhance the growth of BCCs and trichoblastomas in patched heterozygous knockout mice. Nat Med. 1999 Nov;5(11):1285-91.

[9] Auepemkiate S, Boonyaphiphat P, Thongsuksai P p53 expression related to the aggressive infiltrative histopathological feature of basal cell carcinoma. Histopathology. 2002 Jun;40(6):568-73.

[10] Avgerinou G, Nicolis G, Vareltzidis A, Stratigos J. The dermal cellular infiltrate and cell-mediated immunity in skin carcinomas. Dermatologica. 1985; 71(4):238- 42.

[11] Barrett WL, First MR, Aron BS et al. Clinical course of malignancies in renal transplant recipients. Cancer. 1993 Oct 1;72(7):2186-9.

[12] Barr BB, Benton EC, McLaren K. Papillomavirus infection and skin cancer in renal allograft recipients . Lancet. 1989 Jul 22;2(8656):224-5.

[13] Bale AE, Yu KP The hedgehog pathway and basal cell carcinomas Hum Mol Genet. 2001 Apr;10(7):757-62.

[14] Bavinck JN, Kootte AM, van der Woude F et al. HLA-A11-associated resistance to skin cancer in renal-transplant patients. N Engl J Med. 1990 Nov 8;323(19):1350

[15] Bavinck JN, Bastiaens MT, Marugg ME et al. Further evidence for an association of HLA-DR7 with basal cell carcinoma on the tropical island of Saba. Arch Dermatol. 2000 Aug;136(8):1019-22.

[16] Bavinck JN, De Boer A, Vermeer BJ et al. Sunlight, keratotic skin lesions and skin cancer in renal transplant recipients. Br J Dermatol. 1993 Sep; 129(3): 242-9.

[17] Berg RJ, van Kranen HJ, Rebel HG et al. Early p53 alterations in mouse skin carcinogenesis by UVB radiation: immunohistochemical detection of mutant p53 protein in clusters of preneoplastic epidermal cells. Proc Natl Acad Sci U S A. 1996 Jan 9;93(1):274-8.

[18] Benacerraf B. Role of MHC gene products in immune regulation. Science.1981Jun12;212(4500):1229-38

[19] Betti R, Tolomio E, Vergani R, Crosti C. Squamous epithelial carcinoma as a complication of lupus vulgaris. Hautarzt. 2002 Feb;53(2):118-20.

[20] Black AP, Ogg GSThe role of p53 in the immunobiology of cutaneous squamous cell carcinoma. Clin Exp Immunol. 2003 Jun;132(3):379-84. 
[21] Bodak N, Queille S, Avril M F et al. High levels of patched gene mutations in basal-cell carcinomas from patients with xeroderma pigmentosum. Proc Natl Acad Sci U S A. 1999 Apr 27;96(9):5117-22.

[22] Boorstein RJ, Chiu LN, Teebor GW. Phylogenetic evidence of a role for 5hydroxymethyluracil-DNA glycosylase in the maintenance of 5-methylcytosine in DNA. Nucleic Acids Res. 1989 Oct 11;17(19):7653-61.

[23] Bosch FX, Lorincz A, Munoz NThe causal relation between human papillomavirus and cervical cancer. J Clin Pathol. 2002 Apr;55(4):244-65.

[24] Bouwes Bavinck JN, Vermeer BJ, van der Woude FJ et al. Relation between skin cancer and HLA antigens in renal-transplant recipients. $N$ Engl J Med. 1991 Sep 19;325(12):843-8.

[25] Bouwes Bavinck JN. Epidemiological aspects of immunosuppression: role of exposure to sunlight and human papillomavirus on the development of skin cancer. Hum Exp Toxicol. 1995 Jan;14(1):98.

[26] Bouwes Bavinck JN, Hardie DR, Green A et al. The risk of skin cancer in renal transplant recipients in Queensland, Australia. A follow-up study. Transplantation. 1996 Mar 15; 61(5):715-21.

[27] Bouwes-Bavinck JN, Claas FHJ, Hardie DR et al. Relation between HLA antigens and skin cancer in renal transplant recipients in Queensland. Australia J Invest Dermatol 1997;108:708-11.

[28] Bouwes Bavinck JN, Stark S, Petridis AK et al.The presence of antibodies against viruslike particles of epidermodysplasia verruciformis-associated humanpapillomavirus type 8 in patients with actinic keratoses. Br J Dermatol. 2000 Jan;142(1):103-9.

[29] Box NF, Duffy DL, Irving RE et al. Melanocortin-1 receptor genotype is a risk factor for basal and squamous cell carcinoma. J Invest Dermatol. 2001 Feb;116(2):224-9.

[30] Brash DE, Rudolph JA, Simon JA et al. A role for sunlight in skin cancer: UV- induced p53 mutations in squamous cell carcinoma. Proc Natl Acad Sci U S A. 1991 Nov 15;88(22):10124-8.

[31] Brash D E, Ponten J. Skin precancer. Cancer Surv.1998; 32:69-113.

[32] Brown VL, Harwood CA, Crook T et al. p16INK4a and p14ARF tumor suppressor genes are commonly inactivated in cutaneous squamous cell carcinoma. J Invest Dermatol. 2004 May;122(5):1284-92.

[33] Buechner S A, Wernli M, Harr $\mathrm{T}$ et al. Regression of basal cell carcinoma by intralesional interferon-alpha treatment is mediated by CD95 (Apo-1/Fas)-CD95 ligand-induced suicide. J Clin Invest. 1997 Dec 1;100(11):2691-6.

[34] Cabrera T, Garrido V, Concha A et al. HLA molecules in basal cell carcinoma of the skin.Immunobiology.1992Sep;185(5):440-52.

[35] Carless MA, Lea RA, Curran JE et al. The GSTM1 null genotype confers an increased risk for solar keratosis development in an Australian Caucasian population.J Invest Dermatol. 2002 Dec;119(6):1373-8.

[36] Caspari T. How to activate p53.Curr Biol. 2000 Apr 20;10(8):R315-7

[37] Chen JK, Taipale J, Cooper MK et al. Inhibition of Hedgehog signaling by direct binding of cyclopamine to Smoothened. Genes Dev. 2002 Nov 1;16(21):2743-8. 
[38] Chen B, Timiryasova TM, Andres ML et al. Evaluation of combined vaccinia virusmediated antitumor gene therapy with p53, IL-2, and IL-12 in a glioma model. Cancer Gene Ther. 2000 Nov;7(11):1437-47.

[39] Chen K, Craig JC, Shumack S. Oral retinoids for the prevention of skin cancers in solid organ transplant recipients: a systematic review of randomized controlled trials. $\mathrm{Br}$ J Dermatol. 2005 Mar;152(3):518-23.

[40] Cleaver JE. Xeroderma pigmentosum: a human disease in which an initial stage of DNA repair is defective. Proc Natl Acad Sci USA 1969; 63: 428-35.

[41] Coulter LK, Wolber R, Tron VA. Site-specific comparison of p53immunostaining in squamous cell carcinomas. Hum Pathol. 1995 May;26(5): 531-3.

[42] Crispian S. The oral cavity and lips. In Rooks textbook of Dermatology, $7^{\text {th }}$ Edition. Burns T, Breathnach S, Cox N, Griffiths C. Blackwell publishing.66.87

[43] Czarnecki D, Lewis A, Nicholson I et al.HLA-DR1 is not a sign of poor prognosis for the development of multiple basal cell carcinomas. J Am Acad Dermatol. 1992 May;26(5 Pt 1):717-9.

[44] Czarnecki D, Nicholson I, Tait B, Nash C. HLA DR4 is associated with the development of multiple basal cell carcinomas and malignant melanoma. Dermatology. 1993;187(1):16-8.

[45] Dahmane N, Lee J, Robins P et al. Activation of the transcription factor Gli1 and the Sonic hedgehog signalling pathway in skin tumours. Nature. 1997 Oct 23;389 (6653):876-81.

[46] Dantal J, Hourmant M, Cantarovich D et al. Effect of long-term immunosuppression in kidney-graft recipients on cancer incidence: randomised comparison of two cyclosporin regimens. Lancet 1998 Feb 28;351(9103):623-8.

[47] Dausset J, Colombani J, Hors J. Major Histocompatibility complex and cancer, with special reference to human family tumours. (Hodgkin's disease and other malignancies) Cancer Surv 1982;1: 119-47.

[48] de Berker D, Ibbotson S, Simpson NB et al. Reduced experimental contact sensitivity in squamous cell but not basal cell carcinomas of skin. Lancet. 1995Feb18;345(8947):425-6.

[49] Dellavalle RP, Walsh P, Marchbank A et al. CUSP/p63 expression in basal cell carcinoma. Exp Dermatol. 2002 Jun;11(3):203-8.

[50] Demirkan NC, Colakoglu N, Duzcan E. Value of p53 protein in biological behavior of basal cell carcinoma and in normal epithelia adjacent to carcinomas. Pathol Oncol Res. 2000;6(4):272-4.

[51] Di Como CJ, Urist MJ, Babayan I. p63 expression profiles in human normal and tumor tissues. Clin Cancer Res. 2002 Feb;8(2):494-501.

[52] Dirsch VM, Gerbes AL, Vollmar AM.. Ajoene, a compound of garlic, induces apoptosis in human promyeloleukemic cells, accompanied by generation of reactive oxygen species and activation of nuclear factor kappa B. Mol Pharmacol. 1998Mar;53(3):402-7.

[53] Dowell SP, Wilson PO, Derias NW et al. Clinical utility of the immunocytochemical detection of p53 protein in cytological specimens. Cancer Res. 1994 Jun 1;54(11):2914-8 
[54] Duman-Scheel M, Weng L, Xin S et al. Hedgehog regulates cell growth and proliferation by inducing Cyclin D and Cyclin E. Nature. 2002 May 16;417(6886):299-304.

[55] Eklund LK, Lindstrom E, Unden AB et al. Mutation analysis of the human homologue of Drosophila patched and the xeroderma pigmentosum complementation group A genes in squamous cell carcinomas of the skin. Mol Carcinog. 1998 Feb;21(2):87-92.

[56] Elbel M, Carl S, Spaderna S, Iftner T A comparative analysis of the interactions of the E6 proteins from cutaneous and genital papillomaviruses with p53 and E6AP in correlation to their transforming potential. Virology. 1997 Dec 8;239 (1):132-49.

[57] Ellis NA, Groden J, Ye TZ et al . The Bloom's syndrome gene product is homologous to RecQ helicases. Cell. 1995 Nov 17;83(4):655-66

[58] Euvrard S, Kanitakis J, Pouteil-Noble C. Comparative epidemiologic study of premalignant and malignant epithelial cutaneous lesions developing after kidney and heart transplantation.J Am Acad Dermatol. 1995 Aug;33(2 Pt 1):222-9.

[59] Fan H, Oro AE, Scott MP et al. Induction of basal cell carcinoma features in transgenic human skin expressing Sonic Hedgehog. Nat Med. 1997 Jul;3(7):788-92.

[60] FanH, KhavariPA Sonic hedgehog opposes epithelial cell cycle arrest. Cell Biol.1999 Oct 4;147(1):71-6.

[61] Feltkamp MC, Broer R, di Summa FM et al. Seroreactivity to epidermodysplasia verruciformis-related human papillomavirus types is associated with nonmelanoma skin cancer. Cancer Res. 2003 May 15;63(10):2695-700.

[62] Fisher DE Apoptosis in cancer therapy: crossing the threshold. Cell. 1994 Aug 26;78(4):539-42.

[63] Forstrum L. Carcinomatous changes in lupus vulgaris. Ann Clin Res 1969;1:213.

[64] Franceschi S, Dal Maso L, Arniani S et al.Risk of cancer other than Kaposi's sarcoma and non-Hodgkin's lymphoma in persons with AIDS in Italy. Cancer and AIDS Registry Linkage Study. Br J Cancer. 1998 Oct;78(7):966-70.

[65] Gailani MR, Leffell DJ, Ziegler AJ et al. Relationship between sunlight exposure and a key genetic alteration in basal cell carcinoma. Natl Cancer Inst. 1996 Mar 20;88(6):349-54.

[66] Gailani MR, Stahle-Backdahl M, Leffell DJ et al. The role of the human homologue of Drosophila patched in sporadic basal cell carcinomas. Nat Genet. 1996 Sep;14(1):78-81.

[67] GallowayDA,McDougallJK. Human papillomaviruses and carcinomas. Adv Virus Res. 1989;37:125-71.

[68] Garcia-PlataD,MozosE,SierraMA et al. HLA expression in basal cell carcinomas. Invasion Metastasis. 1991;11(3):166-73.

[69] Grachtchouk M, Mo R, Yu S et al. Basal cell carcinomas in mice overexpressing Gli2 in skin. Nat Genet. 2000 Mar;24(3):216-7.

[70] Granstein RD.Cytokines and photocarcinogenesis. Photochem Photobiol. 1996 Apr;63(4):390-4.

[71] Griffiths HR, Mistry P, Herbert KE, Lunec J. Molecular and cellular effects of ultraviolet light-induced genotoxicity. Crit Rev Clin Lab Sci. 1998 Jun;35(3): 89-237. 
[72] Hahn H, Wicking C, Zaphiropoulous PG et al. Mutations of the human homolog of Drosophila patched in the nevoid basal cell carcinoma syndrome. Cell. 1996 Jun 14;85(6):841-51.

[73] Hajeer A H, Lear J T, Ollier WE et al. Preliminary evidence of an association of tumour necrosis factor microsatellites with increased risk of multiple basal cell carcinomas.BrJDermatol.2000Mar;142(3):441-5.

[74] Hall PA, McKee PH, Menage HD et al. High levels of p53 protein in UV- irradiated normal humans kin. Oncogene. 1993 Jan;8(1):203-7.

[75] Hall J, English DR, Artuso M, et al. DNA repair capacity as a risk factor for nonmelanocytic skin cancer-a molecular epidemiology study. Int J Cancer 1994; 58: 179-84.

[76] Han J, Colditz GA, Liu JS, Hunter DJ. Genetic variation in XPD, sun exposure, and risk of skin cancer. Cancer Epidemiol Biomarkers Prev. 2005 Jun;14(6):1539-44

[77] Han J, Colditz GA, Samson LD, Hunter DJ. Polymorphisms in DNA double- strand break repair genes and skin cancer risk. Cancer Res. 2004 May 1;64(9):3009-13.

[78] Han J, Hankinson SE, Colditz GA, Hunter DJ. Genetic variation in XRCC1, sun exposure, and risk of skin cancer.Br J Cancer. 2004 Oct 18;91(8):1604-9.

[79] Hartevelt MM, Bavinck JN, Kootte AM et al. Incidence of skin cancer after renal transplantation in The Netherlands. Transplantation. 1990 Mar;49(3):506-9.

[80] Harwood CA, Proby CM. Human papillomaviruses and non-melanoma skin cancer. Curr Opin Infect Dis. 2002 Apr;15(2):101-14.

[81] Harwood CA, Leedham-Green M, Leigh IM, Proby CM.Low-dose retinoids in the prevention of cutaneous squamous cell carcinomas in organ transplant recipients: a 16-year retrospective study. Arch Dermatol. 2005 Apr;141(4):456- 64.

[82] Haupt Y, Maya R, Kazaz A et al. Mdm2 promotes the rapid degradation of p53.Nature. 1997 May 15;387(6630):296-9.

[83] Hayes J D, Pulford DJ .The glutathione S-transferase supergene family: regulation of GST and the contribution of the isoenzymes to cancer chemoprotection and drug resistance. Crit Rev Biochem Mol Biol. 1995;30(6):445-600.

[84] Heagerty A H, Fitzgerald D, Smith A. Glutathione S-transferase GSTM1 phenotypes and protection against cutaneous tumours. Lancet. 1994Jan29; 343(8892):266-8.

[85] Heagerty A, Smith A, English J et al. Susceptibility to multiple cutaneous basal cell carcinomas: significant interactions between glutathione S-transferase GSTM1 genotypes, skin type and male gender. Br J Cancer. 1996 Jan;73(1):44-8

[86] Hoffman EJ, Cancer and the search for selective biochemical inhibitors. Boca Raton, FL, CRC Press, 1999.

[87] Hollstein M, Sidransky D, Vogelstein B et al. p53 mutations in human cancers. Science. 1991 Jul 5;253(5015):49-53.

[88] Holme SA, Malinovszky K, Roberts DL Changing trends in non-melanoma skin cancer in South Wales, 1988-98. Br J Dermatol. 2000 Dec;143(6):1224-9.

[89] Huang Z. Bcl-2 family proteins as targets for anticancer drug design. Oncogene. 2000 Dec 27;19(56):6627-31. 
[90] Ishida T, Chada S, Stipanov M et al. Dendritic cells transduced with wild-type p53 gene elicit potent anti-tumour immune responses. Clin Exp Immunol. 1999 Aug;117(2):244-51

[91] Jackson S, Harwood C, Thomas M et al. Role of Bak in UV-induced apoptosis in skin cancer and abrogation by HPV E6 proteins. Genes Dev. 2000 Dec 1;14(23):3065-73.

[92] Jee S H, Shen S C, Tseng C R et al. Curcumin induces a p53-dependent apoptosis in humanbasalcellcarcinomacells. J Invest Dermatol. 1998 Oct;111(4):656-61.

[93] Jee SH, Shen SC, Chiu HC et al. Overexpression of interleukin-6 in human basal cell carcinoma cell lines increases anti-apoptotic activity and tumorigenic potency. Oncogene. 2001 Jan 11;20(2):198-208.

[94] Jensen P, Hansen S, Moller BJ et al . Skin cancer in kidney and heart transplant recipients and different long-term immunosuppressive therapy regimens. Am Acad Dermatol 1999 Feb;40(2 Pt 1):177-86

[95] Johnson RL, Rothman AL, Xie J et al. Human homolog of patched, a candidate gene for the basal cell nevus syndrome. Science. 1996 Jun 14;272(5268):1668-71.

[96] Jonason AS, Kunala S, Price GJ et al. Frequent clones of p53-mutated keratinocytes in normal human skin. Proc Natl Acad Sci U S A. 1996 Nov 26;93(24):14025-9.

[97] Kalka K, Merk H, Mukhtar H et al. Photodynamic therapy in dermatology.J Am Acad Dermatol. 2000 Mar;42(3):389-413; quiz 414-6.

[98] Kallassy M, Toftgard R, Ueda M et al. Patched (ptch)-associated preferential expression of smoothened (smoh) in human basal cell carcinoma of the skin. Cancer Res. 1997 Nov 1;57(21):4731-5

[99] Karagas MR, Greenberg ER. Unresolved issues in the epidemiology of basal cell and squamous cell skin cancer. In: Skin cancer: Mechanisms and human relevance. (Mukhtar H., ed.) Boca Raton, Florida: CRC Press, 1995: 79-86.

[100] Kaplan RP. Cancer complicating chronic ulcerative and scarring mucocutaneous disorders. Adv Derm 1987;2: 19-46.

[101] Kastan MB, Onyekwere O, Sidransky D et al. Participation of p53 protein in the cellular response to DNA damage. Cancer Res. 1991 Dec 1;51(23 Pt 1):6304-11.

[102] Katayama H, Sasai K, Kawai H et al. Phosphorylation by aurora kinase A induces Mdm2-mediated destabilization and inhibition of p53. Nat Genet. 2004 Jan;36(1):5562.

[103] Kerb R, Brockmoller J, Reum T et al. Deficiency of glutathione S-transferases T1 and M1 as heritable factors of increased cutaneous UV sensitivity. I Invest Dermatol. 1997 Feb;108(2):229-32.

[104] Kim MY, Park HJ, Baek SC et al. Mutations of the p53 and PTCH gene in basal cell carcinomas: UV mutation signature and strand bias. J Dermatol Sci. 2002 May;29(1):1-9.

[105] Kitao S, Lindor NM, Shiratori M et al. Rothmund-thomson syndrome responsible gene, RECQL4: genomic structure and products. Genomics 1999 Nov 1;61(3):268-76.

[106] Knight SW, Heiss NS, Vulliamy TJ et al. X-linked dyskeratosis congenita is predominantly caused by missense mutations in the DKC1 gene. Am J Hum Genet. 1999 Jul;65(1):50-8. 
[107] Knudson A G Jr. Hereditary cancer, oncogenes, and antioncogenes. Cancer Res. 1985Apr;45(4):1437-43.

[108] Koehl GE, Andrassy J, Guba M et al. Rapamycin protects allografts from rejection while simultaneously attacking tumors in immunosuppressed mice. Transplantation. 2004 May 15;77(9):1319-26.

[109] Koike C, Mizutani T, Ito T, Shimizu Y. Introduction of wild-type patched gene suppresses the oncogenic potential of human squamous cell carcinoma cell lines including A431. Oncogene. 2002 Apr 18;21(17):2670-8.

[110] Kovach BT, Sams HH, Stasko T. Systemic strategies for chemoprevention of skin cancers in transplant recipients. Clin Transplant. 2005 Dec;19(6):726-34.

[111] Kreimer-Erlacher H, Seidl H, Back B, Kerl H, Wolf P. High mutation frequency at Haras exons 1-4 in squamous cell carcinomas from PUVA-treated psoriasis patients. Photochem Photobiol. 2001 Aug;74(2):323-30.

[112] Kricker A, Armstrong BK, English DR, Heenan PJ. Does intermittent sun exposure cause basal cell carcinoma? A case-control study in Western Australia. Int J Cancer 1995; 60: 489-94.

[113] Kricker A, Armstrong BK, English DR, Heenan PJ. A dose-response curve for sun exposure and basal cell carcinoma. Int J Cancer. 1995 Feb ;60(4):482- 8.

[114] Kripke ML. Ultraviolet radiation and immunology: something new under the sun-presidentialaddress. Cancer Res. 1994 Dec 1;54(23):6102-5.

[115] Kubbutat MH, Jones SN, Vousden KH. Regulation of p53 stability by Mdm2. Nature. 1997 May 15;387(6630):299-303.

[116] Kunisada M, Budiyanto A, Bito T et al. Retinoic acid suppresses telomerase activity in HSC-1 human cutaneous squamous cell carcinoma. Br J Dermatol. 2005 Mar;152(3):435-43.

[117] Kutler DI, Wreesmann VB, Goberdhan A et al. Human papillomavirus DNA and p53 polymorphisms in squamous cell carcinomas from Fanconi anemia patients. J Natl Cancer Inst. 2003 Nov 19;95(22):1718-21.

[118] Lavker RM, Miller SJ, Sun TT. Epithelial stem cells, hair follicles, and tumor formation. Recent Results Cancer Res. 1993;128:31-43.

[119] Lear JT, Heagerty AH, Smith A et al.Multiple cutaneous basal cell carcinomas: glutathione S-transferase (GSTM1, GSTT1) and cytochrome P450 (CYP2D6, CYP1A1) polymorphisms influence tumour numbers and accrual. Carcinogenesis. 1996 Sep;17(9):1891-6.

[120] Lear JT, Smith AG, Heagerty AH. et al. Truncal site and detoxifying enzyme polymorphisms significantly reduce time to presentation of further primary cutaneous basal cell carcinoma. Carcinogenesis.1997Aug;18(8):1499-503.

[121] Lear JT, Smith AG, Strange RC, Fryer AA Detoxifying enzyme genotypes and susceptibility to cutaneous malignancy. Br J Dermatol. 2000 Jan;142(1):8-15.

[122] Leite JL, Stolf HO, Reis NA, Ward LS. Human herpesvirus type 6 and type 1 infection increases susceptibility to nonmelanoma skin tumors. Cancer Lett. 2005 Jun 28;224(2):213-9. 
[123] Liang SB, Ohtsuki Y, Furihata M et al.Sun-exposure- and aging-dependent p53 protein accumulation results in growth advantage for tumour cells in carcinogenesis of nonmelanocytic skin cancer. Virchows Arch. 1999 Mar;434(3):193-9.

[124] Liefer KM, Koster MI, Wang XJ et al. Down-regulation of p63 is required for epidermal UV-B-induced apoptosis. Cancer Res. 2000 Aug 1;60(15):4016-20.

[125] Little NA, Jochemsen AG.p63. Int J Biochem Cell Biol. 2002 Jan;34(1):6-9.

[126] Lobo D V, Chu P, Grekin R C et al. Nonmelanoma skin cancers and infection with the human immunodeficiency virus.ArchDermatol.1992May; 128(5):623-7.

[127] Lotan R. Retinoids in cancer chemoprevention. Faseb J. 1996 Jul;10(9):1031-9

[128] Lookingbill DP, Lookingbill GL, Leppard B. Actinic damage and skin cancer in albinos in northern Tanzania: findings in 164 patients enrolled in an outreach skin care program. J Am Acad Dermatol. 1995 Apr;32(4):653-8.

[129] Lu YP, Lou YR, Xie JG et al. Inhibitory effect of black tea on the growth of established skin tumors in mice: effects on tumor size, apoptosis, mitosis and bromodeoxyuridine incorporation into DNA. Carcinogenesis. 1997 Nov;18(11):2163-9.

[130] Madariaga J, Fromowitz F, Phillips M.Squamous cell carcinoma in congenital ichthyosis with deafness and keratitis. A case report and review of the literature. Cancer. 1986 May 15;57(10):2026-9.

[131] Majewski S, Jablonska S Epidermodysplasia verruciformis as a model of human papillomavirus-induced genetic cancer of the skin. Arch Dermatol. 1995 Nov;131(11):1312-8.

[132] Maki CG, Huibregtse JM, Howley PM.In vivo ubiquitination and proteasomemediated degradation of p53(1).Cancer Res. 1996 Jun 1;56(11):2649-54.

[133] Malkin D, Li FP, Strong LC et al . Germ line p53 mutations in a familial syndrome of breast cancer, sarcomas, and other neoplasms. Science. 1990 Nov 30;250(4985):1233-8.

[134] Mallipeddi R, Wessagowit V, South AP et al. Reduced expression of insulin-like growth factor-binding protein-3 (IGFBP-3) in Squamous cell carcinoma complicating recessive dystrophic epidermolysis bullosa. J Invest Dermatol. 2004 May;122(5):1302-9.

[135] Marks R, Foley P, Goodman G et al. Spontaneous remission of solar keratoses: the case for conservative management. Br J Dermatol. 1986 Dec;115(6):649-55.

[136] Masini C, Fuchs PG, Gabrielli F et al. Evidence for the association of human papillomavirus infection and cutaneous squamous cell carcinoma in immunocompetent individuals. Arch Dermatol. 2003 Jul;139(7):890-4.

[137] Mayordomo JI, Loftus DJ, Sakamoto $\mathrm{H}$ et al. Therapy of murine tumors with p53 wildtype and mutant sequence peptide-based vaccines. J Exp Med. 1996 Apr 1;183(4):1357-65.

[138] McGregor JM, Proby CM. Skin cancer in transplant recipients. Lancet. 1995 Oct 7;346(8980):964-5.

[139] McLelland J, Rees A, Williams G et al. The incidence of immunosuppression- related skin disease in long-term transplant patients. Transplantation. 1988 Dec;46(6):871-4. 
[140] Miller BH, Shavin JS, Cognetta A Nonsurgical treatment of basal cell carcinomas with intralesional 5-fluorouracil/epinephrine injectable gel. J Am Acad Dermatol. 1997 Jan;36(1):72-7.

[141] Miller SJ, Sun TT, Lavker RM. Hair follicles, stem cells, and skin cancer. J Invest Dermatol.1993Mar; 100(3):288S-294S.

[142] Mills AA, Zheng B, Wang X J et al. p63 is a p53 homologue required for limb and epidermal morphogenesis. Nature. 1999 Apr 22;398(6729):708-13.

[143] Moscow JA, Townsend AJ, Goldsmith $\mathrm{M}$ et al. Isolation of the human anionic glutathione S-transferase cDNA and the relation of its gene expression to estrogenreceptor content in primary breast cancer .Proc Natl Acad Sci U S A. 1988 Sep;85(17):6518-22.

[144] Myskowski P L, Safai B, Good R A. Decreased lymphocyte blastogenic responses in patients with multiple basal cellcarcinoma. J Am Acad Dermatol. 1981 Jun;4(6):711-4.

[145] Nakaseko H, Kobayashi M, Akita Y et al. Histological changes and involvement of apoptosis after photodynamic therapy for actinic keratoses. Br J Dermatol. 2003, Jan;148(1):122-7.

[146] Nakazawa H, English D, Randell PLProc et al. UV and skin cancer: specific p53 gene mutation in normal skin as a biologically relevant exposure measurement. Natl Acad Sci U S A. 1994 Jan 4;91(1):360-4.

[147] Nataraj AJ, Trent JC 2nd, Ananthaswamy HN. p53 gene mutations and photocarcinogenesis. Photochem Photobiol. 1995 Aug;62(2):218-30

[148] Nelson HH, Christensen B, Karagas MR. The XPC poly-AT polymorphism in nonmelanoma skin cancer. Cancer Lett. 2005 May 26;222(2):205-9.

[149] Nikitina EY, Chada S, Muro-Cacho C et al An effective immunization and cancer treatment with activated dendritic cells transduced with full-length wild-type p53. Gene Ther. 2002 Mar;9(5):345-52.

[150] Nilsson $M$, Unden $A B$, Krause $D$ et al. Induction of basal cell carcinomas and trichoepitheliomas in mice overexpressing GLI-1.Proc Natl Acad Sci U S A. 2000 Mar 28;97(7):3438-43.

[151] O'Donovan P, Perrett CM, Zhang X et al. Azathioprine and UVA light generate mutagenic oxidative DNA damage. Science. 2005 Sep 16;309 (5742):1871-4.

[152] Ondrus D, Pribylincova V, Breza J et al. The incidence of tumours in renal transplant recipients with long-term immunosuppressive therapy. Int Urol Nephrol. 1999;31(4):417-22

[153] Ong CS, Keogh AM, Kossard S et al. Skin cancer in Australian heart transplant recipients.J Am Acad Dermatol. 1999 Jan;40(1):27-34.

[154] Oro A E, Higgins K M, Hu Z et al. Basal cell carcinomas in mice overexpressing sonic hedgehog. Science. 1997 May 2;276(5313):817-21.

[155] Otley CC, Pittelkow MR. Skin cancer in liver transplant recipients. Liver Transpl. 2000 May;6(3):253-62.

[156] Pagano G, Zatterale A, Degan P et al. Multiple involvement of oxidative stress in Werner syndrome phenotype. Biogerontology. 2005;6(4):233-43. 
[157] Pagano G, Zatterale A, Degan P et al et al. In vivo prooxidant state in Werner syndrome (WS): results from three WS patients and two WS heterozygotes. Free Radic Res. 2005 May;39(5):529-33.

[158] Park CB, Fukamachi K, Takasuka N et al. Rapid induction of skin and mammary tumors in human c-Ha-ras proto-oncogene transgenic rats by treatment with 7,12dimethylbenz[a]anthracene followed by 12-O- tetradecanoylphorbol 13-acetate. Cancer Sci. 2004 Mar;95(3):205-10.

[159] Parsa R, Yang A, McKeon F et al. Association of p63 with proliferative potential in normal and neoplastic human keratinocytes. J Invest Dermatol. 1999 Dec;113(6):1099105.

[160] Pemble S, Schroeder KR, Spencer SR et al. Human glutathione S-transferase theta (GSTT1): cDNA cloning and the characterization of a genetic polymorphism. Biochem J. 1994 May 15;300 ( Pt 1):271-6.

[161] Penn I. The changing pattern of posttransplant malignancies. Transplant Proc 1991 Feb;23(1 Pt 2):1101-3.

[162] Penn I. Tumors after renal and cardiac transplantation. Hematol Oncol Clin North Am. 1993 Apr;7(2):431-45

[163] Peterkin GAG. Malignant change in erythema ab igne. BMJ. 1955; ii; 1599-602.

[164] Petersen TR, Bregenholta S, Pedersen LO et al.Human p53(264-272) HLA-A2 binding peptide is an immunodominant epitope in DNA-immunized HLA-A2 transgenic mice. Cancer Lett. 1999 Apr 1;137(2):183-91.

[165] Petkovic M, Dietschy T, Freire R et al. J Cell Sci. The human Rothmund- Thomson syndrome gene product, RECQL4, localizes to distinct nuclear foci that coincide with proteins involved in the maintenance of genome stability. J Cell Sci. 2005 Sep 15;118(Pt 18):4261-9

[166] Pfister H. Chapter 8: Human papillomavirus and skin cancer. J Natl Cancer Inst Monogr. 2003;(31):52-6.

[167] Pierceall WE, Goldberg LH, Tainsky MA et al. Ras gene mutation and amplification in human nonmelanoma skin cancers. Mol Carcinog. 991;4(3):196-202.

[168] Ping XL, Ratner D, Zhang H et al.PTCH mutations in squamous cell carcinoma of the skin.J Invest Dermatol. 2001 Apr;116(4):614-6.

[169] Piquero-Casals J, Okubo AY, Nico MM. Rothmund-thomson syndrome in three siblings and development of cutaneous squamous cell carcinoma. Pediatr Dermatol. 2002 Jul-Aug;19(4):312-6.

[170] Pritchard BN, Youngberg GA . Atypical mitotic figures in basal cell carcinoma. A review of 208 cases. Am J Dermatopathol. 1993 Dec;15(6):549-52.

[171] Purdie KJ, Pennington J, Proby CM et al. The promoter of a novel human papillomavirus (HPV77) associated with skin cancer displays UV responsiveness, which is mediated through a consensus p53 binding sequence. EMBO J. 1999 Oct 1;18(19):5359-69.

[172] Purdie KJ, Surentheran T, Sterling JC et al. Human papillomavirus gene expression in cutaneous squamous cell carcinomas from immunosuppressed and immunocompetent individuals. J Invest Dermatol. 2005 Jul;125(1):98-107. 
[173] Quade BJ, Yang A, Wang Y et al. Expression of the p53 homologue p63 in early cervical neoplasia. Gynecol Oncol. 2001 Jan;80(1):24-9.

[174] Quinn AG, Sikkink S, Rees JL Basal cell carcinomas and squamous cell carcinomas of human skin show distinct patterns of chromosome loss. Cancer Res. 1994 Sep 1;54(17):4756-9.

[175] Rady P, Scinicariello F, Wagner RF Jr et al. p53 mutations in basal cell carcinomas. Cancer Res. 1992 Jul 1;52(13):3804-6.

[176] Ragni MV, Belle SH, Jaffe RA et al. Acquired immunodeficiency syndrome-associated non-Hodgkin's lymphomas and other malignancies in patients with hemophilia.Blood.1993Apr1;81(7):1889-97.

[177] Ramachandran S, Lear JT, Ramsay H, et al. Presentation with multiple cutaneous basal cell carcinomas: Association of glutathione S-transferase and cytochrome P450 genotypes with clinical phenotype. Cancer Epidemiol Biomarkers Prev 1999; 8: 61-7.

[178] Ramachandran S, Fryer AA, Lear JT, et al. Basal Cell Carcinoma: Tumor clustering is associated with increased accrual in high-risk subgroups. Cancer 2000; 89: 1012-8

[179] Ramachandran S, Fryer AA, Smith AG, et al. Cutaneous basal cell carcinomas: Distinct host factors are associated with the development of tumors on the trunk and head and neck. Cancer 2001; 92: 354-8.

[180] Raza H, Awasthi YC, Zaim MT et al.Glutathione S-transferases in human and rodent skin: multiple forms and species-specific expression. I Invest Dermatol. 1991Apr;96(4):463-7.

[181] Reis-Filho JS, Torio B, Albergaria A, Schmitt FC. p63 expression in normal skin and usual cutaneous carcinomas. J Cutan Pathol. 2002 Oct;29(9):517-23.

[182] Rodriguez-Villanueva J, McDonnell TJ. Induction of apoptotic cell death in nonmelanoma skin cancer by interferon-alpha. Int J Cancer. 1995 Mar 29;61(1):110-4.

[183] Romkes M, Chern HD, Lesnick TG e al. Association of low CYP3A activity with p53 mutation and CYP2D6 activity with $\mathrm{Rb}$ mutation in human bladder cancer. Carcinogenesis. 1996 May;17(5):1057-62.

[184] Rompel R, Petres J, Kaupert K et al Human leukocyte antigens and multiple basal cell carcinomas. Recent Results. Cancer Res. 1995;139:297-302.

[185] Ronen D, Schwartz D, Teitz Y et al. Induction of HL-60 cells to undergo apoptosis is determined by high levels of wild-type p53 protein whereas differentiation of the cells is mediated by lower p53 levels. Cell Growth Differ.1996Jan;7(1):21-30.

[186] Rosenstein BS, Phelps RG, Weinstock MA et al. p53 mutations in basal cell carcinomas arising in routine users of sunscreens. Photochem Photobiol. 1999 Nov;70(5):798-806.

[187] Rosso S, Zanetti R, Martinez C, et al. The multicentre south European study "Helios" II: different sun exposure patterns in the aetiology of basal cell and squamous cell carcinomas of the skin. Br J Cancer. 1996; 73: 1447-54.

[188] Roth J, Dittmer D, Rea D et al. p53 as a target for cancer vaccines: recombinant canarypox virus vectors expressing p53 protect mice against lethal tumor cell challenge. Proc Natl Acad Sci U S A. 1996 May 14;93(10):4781-6.

[189] Ruhland A, de Villiers EMOpposite regulation of the HPV 20-URR and HPV 27-URR promoters by ultraviolet irradiation and cytokines. Int J Cancer. 2001 Mar 15;91(6):828-34. 
[190] Ruiter DJ, Bergman W, Welvaart K et al. Immunohistochemical analysis of malignant melanomas and nevocellular nevi with monoclonal antibodies to distinct monomorphic determinants of HLA antigens. Cancer Res. 1984 Sep;44(9):3930-5.

[191] Salasche SJ. Epidemiology of actinic keratoses and squamous cell carcinoma. J Am Acad Dermatol. 2000 Jan;42(1 Pt 2):4-7.

[192] Sarhanis P, Redman C, Perrett C et al. Epithelial ovarian cancer: influence of polymorphism at the glutathione S-transferase GSTM1 and GSTT1 loci on p53 expression.Br J Cancer. 1996 Dec;74(11):1757-61.

[193] Shamanin V, zur Hausen H, Lavergne D J Natl. Human papillomavirus infections in nonmelanoma skin cancers from renal transplant recipients and nonimmunosuppressed patients. Cancer Inst. 1996 Jun 19;88(12):802-11.

[194] Shields JM, Pruitt K, McFall A et al. Understanding Ras: 'it ain't over 'til it's over'. Trends Cell Biol. 2000 Apr;10(4):147-54.

[195] Siliciano JD, Canman CE, Taya Y et al. DNA damage induces phosphorylation of the amino terminus of p53.Genes Dev. 1997 Dec 15;11(24):3471-81.

[196] Sionov RV, Haupt Y. The cellular response to p53: the decision between life and death. Oncogene. 1999 Nov 1;18(45):6145-57.

[197] Sitz KV, Keppen M, Johnson DF Metastatic basal cell carcinoma in acquired immunodeficiency syndrome-elated complex. JAMA. 1987 Jan 16;257(3):340-3.

[198] Soufir N, Daya-Grosjean L, de La Salmoniere P et al. Association between INK4a-ARF and p53 mutations in skin carcinomas of xeroderma pigmentosum patients. J Natl Cancer Inst. 2000 Nov 15;92(22):1841-7.

[199] Soussi T. The p53 tumor suppressor gene: from molecular biology to clinical investigation. Ann N Y Acad Sci. 2000 Jun;910:121-37; discussion 137-9.

[200] Spencer JM, Kahn SM, Jiang W et al. Activated ras genes occur in human actinic keratoses, premalignant precursors to squamous cell carcinomas. Arch Dermatol. 1995 Jul;131(7):796-800.

[201] Sprong H, van der Sluijs P, van Meer G How proteins move lipids and lipids move proteins. Nat Rev Mol Cell Biol. 2001 Jul;2(7):504-13.

[202] Stanley M, Coleman N, Chambers M The host response to lesions induced by human papillomavirus. Ciba Found Symp. 1994;187:21-32; discussion 32-44.

[203] Steigleder GK. Metastasizing basalioma in AIDS. Z Hautkr. 1987 May 1;62(9):661.

[204] Stern RS, Lunder EJ. Risk of squamous cell carcinoma and methoxsalen (psoralen) and UV-A radiation (PUVA): a meta-analysis. Arch Dermatol 1998;134: 1582-5.

[205] Stone DM, Murone M, Luoh S et al. Characterization of the human suppressor of fused, a negative regulator of the zinc-finger transcription factor Gli.J Cell Sci. 1999 Dec;112 ( Pt 23):4437-48.

[206] Storey A, Thomas M, Kalita A et al. Nature. Role of a p53 polymorphism in the development of human papillomavirus-associated cancer. Nature,1998 May 21;393(6682):229-34.

[207] Streilein JW. Sunlight and skin-associated lymphoid tissues (SALT): if UVB is the trigger and TNF alpha is its mediator, what is the message? J Invest Dermatol. 1993 Jan;100(1):47S-52S. 
[208] Taipale J, Chen J K, Cooper M K et al. Effects of oncogenic mutations in Smoothened and Patched can be reversed by cyclopamine. Nature. 2000 Aug 31;406(6799):1005-9.

[209] TasS, Avci O, Induction of the differentiation and apoptosis of tumour cells in vivo with efficiency and selectivity. Eur J Dermatol2004;14:96-102

[210] Thissen MR, Schroeter C A, Neumann H A et al. Photodynamic therapy with deltaaminolaevulinic acid for nodular basal cell carcinomas using a prior debulking technique.Br J Dermatol. 2000 Feb;142(2):338-9.

[211] Thomas M, Pim D, Banks L.The role of the E6-p53 interaction in the molecular pathogenesis of HPV. Oncogene. 1999 Dec 13;18(53):7690-700.

[212] Tilli CM, Stavast-Kooy AJ, Vuerstaek JD et al. The garlic-derived organosulfur component ajoene decreases basal cell carcinoma tumor size by inducing apoptosis. Arch Dermatol Res. 2003 Jul;295(3):117-23.

[213] Tokunaga N, Murakami T, Endo Y et al. Human monocyte-derived dendritic cells pulsed with wild-type p53 protein efficiently induce CTLs against p53 overexpressing human cancer cells. Clin Cancer Res. 2005 Feb 1;11(3):1312-8

[214] Unger T, Juven-Gershon T, Moallem E et al. Critical role for Ser20 of human p53 in the negative regulation of p53 by Mdm2. EMBO J. 1999 Apr 1;18(7):1805-14.

[215] van der Riet P, Nawroz H, Hruban RH et al. Frequent loss of chromosome 9p21-22 early in head and neck cancer progression.Cancer Res. 1994 Mar 1;54(5):1156-8.

[216] Vierboom MP, Nijman HW, Offringa et al. Tumor eradication by wild-type p53specific cytotoxic T lymphocytes. J Exp Med. 1997 Aug 29;186(5):695-704.

[217] Vulliamy T, Marrone A, Goldman F et al .The RNA component of telomerase is mutated in autosomal dominant dyskeratosis congenita. Nature. 2001 Sep 27;413(6854):432-5.

[218] Wang LL, Levy ML, Lewis RA .Clinical manifestations in a cohort of 41 RothmundThomson syndrome patients. Am J Med Genet. 2001 Jul 2;102(1):11- 7.

[219] Wang TY, Chen BF, Yang YC et al Histologic and immunophenotypic classification of cervical carcinomas by expression of the p53 homologue p63: a study of 250 cases. Hum Pathol. 2001 May;32(5):479-86.

[220] Weimar VM, Ceilley RI, Goeken JACell-mediated immunity in patients with basal and squamous cell skin cancer. J Am Acad Dermatol. 1980 Feb;2(2):143-7.

[221] Weinstock MA, Coulter S, Bates J et al. Human papillomavirus and widespread cutaneous carcinoma after PUVA photochemotherapy. Arch Dermatol. 1995 Jun;131(6):701-4.

[222] Wicking C, Smyth I, Bale A The hedgehog signalling pathway in tumorigenesis and development. Oncogene. 1999 Dec 20;18(55):7844-51.

[223] Wikonkal N M, Brash D E. Ultraviolet radiation induced signature mutations in photocarcinogenesis.J Investig Dermatol Symp Proc. 1999 Sep;4(1):6-10.

[224] Xie J, Murone M, Luoh SM et al Activating Smoothened mutations in sporadic basalcell carcinoma Nature. 1998 Jan 1;391(6662):90-2.

[225] Yarosh DB, Pena AV, Nay SL et al. Calcineurin inhibitors decrease DNA repair and apoptosis in human keratinocytes following ultraviolet B irradiation. I Invest Dermatol. 2005 Nov;125(5):1020-5. 
[226] Yengi L, Inskip A, Gilford J et alPolymorphism at the glutathione S-transferase locus GSTM3: interactions with cytochrome P450 and glutathione S-transferase genotypes as risk factors for multiple cutaneous basal cell carcinoma. Cancer Res. 1996 May 1;56(9):1974-7

[227] Yu CE, Oshima J, Fu YH, et al Positional cloning of the Werner's syndrome gene. Science. 1996 Apr 12;272(5259):258-62.

[228] Ziegler A, Leffell D J, Kunala S et al. Mutation hotspots due to sunlight in the p53 gene of nonmelanoma skin cancers. Proc Natl Acad Sci U S A. 1993 May1;90(9):4216-20.

[229] Ziegler A, Jonason AS, Leffell DJ et al. Sunburn and p53 in the onset of skin cancer. Nature. 1994 Dec 22-29; 372(6508):773-6. 


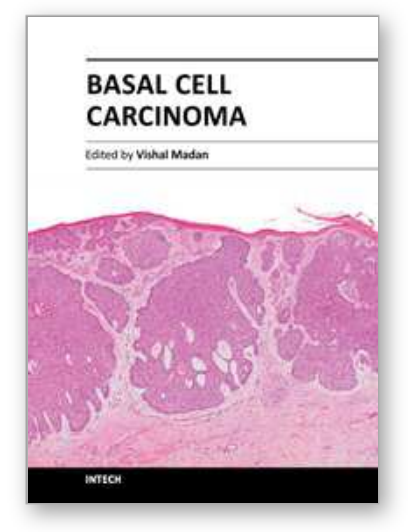

\author{
Basal Cell Carcinoma \\ Edited by Dr. Vishal Madan
}

ISBN 978-953-51-0309-7

Hard cover, 126 pages

Publisher InTech

Published online 14, March, 2012

Published in print edition March, 2012

Basal cell carcinoma is the commonest cutaneous malignancy. The last decade has witnessed exponential research which has broadened our understanding of the pathogenesis of basal cell carcinomas. This is also important from a therapeutic point of view as targeted approach to therapy is now being increasingly experimented. Although it is impossible to condense and present all good research in one book, the authors have to be commended on presenting their research on several aspects of basal cell carcinoma in a succinct manner, which shall not only enhance our understanding of, but also hopefully via this open exchange of ideas pave ways for successful targeted therapy of the commonest human cancer.

\title{
How to reference
}

In order to correctly reference this scholarly work, feel free to copy and paste the following:

Venura Samarasinghe, John T. Lear, Vishal Madan (2012). Genomics of Basal and Squamous Cell Carcinomas, Basal Cell Carcinoma, Dr. Vishal Madan (Ed.), ISBN: 978-953-51-0309-7, InTech, Available from: http://www.intechopen.com/books/basal-cell-carcinoma/genomics-of-basal-and-squamous-cell-carcinomas-

\section{INTECH}

open science / open minds

\section{InTech Europe}

University Campus STeP Ri

Slavka Krautzeka 83/A

51000 Rijeka, Croatia

Phone: +385 (51) 770447

Fax: +385 (51) 686166

www.intechopen.com

\section{InTech China}

Unit 405, Office Block, Hotel Equatorial Shanghai

No.65, Yan An Road (West), Shanghai, 200040, China

中国上海市延安西路65号上海国际贵都大饭店办公楼 405 单元

Phone: +86-21-62489820

Fax: +86-21-62489821 
(C) 2012 The Author(s). Licensee IntechOpen. This is an open access article distributed under the terms of the Creative Commons Attribution 3.0 License, which permits unrestricted use, distribution, and reproduction in any medium, provided the original work is properly cited. 